Fall 7-1-2003

\title{
The Right to Assistance of Counsel in Military and War Crimes Tribunals: An International and Domestic Law Analysis
}

Joshua E. Kastenberg

University of New Mexico - School of Law

Follow this and additional works at: https://digitalrepository.unm.edu/law_facultyscholarship

Part of the Law Commons

\section{Recommended Citation}

Joshua E. Kastenberg, The Right to Assistance of Counsel in Military and War Crimes Tribunals: An International and Domestic Law Analysis, 14 Indiana International and Comparative Law Review 175 (2003).

Available at: https://digitalrepository.unm.edu/law_facultyscholarship/425

This Article is brought to you for free and open access by the UNM School of Law at UNM Digital Repository. It has been accepted for inclusion in Faculty Scholarship by an authorized administrator of UNM Digital Repository. For more information, please contact amywinter@unm.edu, Isloane@salud.unm.edu,sarahrk@unm.edu.

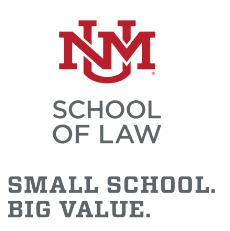

BIG VALUE. 


\title{
THE RIGHT TO ASSISTANCE OF COUNSEL IN MILITARY AND WAR CRIMES TRIBUNALS: AN INTERNATIONAL AND DOMESTIC LAW ANALYSIS
}

\author{
Major Joshua E. Kastenberg*
}

Much recent international and criminal law scholarship deals with topics such as universal jurisdiction, evolving definitions of international crimes, and the application of accountability principles developed during international tribunals such as the ad hoc International Criminal Tribunal for the former Yugoslavia (ICTY), and the ad hoc International Criminal Tribunal for Rwanda (ICTR). However, few have devoted to the right to a fair trial. ${ }^{1}$ In particular, international standards of effective defense counsel representation for accused persons appear to be ignored by mainstream international law scholarship. In United States jurisprudence, there are a multitude of federal and state cases dealing with the Constitution's Sixth Amendment right to counsel provision. Additionally, there is a substantial amount of legal scholarship regarding a defendant's rights to a fair trial in the United States. Despite this, little attention has been paid to competency of counsel issues in a United States military commission. The United States has not prosecuted

* Major Joshua E. Kastenberg, USAF, Judge Advocate General's Corps; LLM (International \& Comparative Law with Highest Distinction) Georgetown University, JD (Deans List) Marquette University, BA, UCLA. Major Kastenberg is currently the deputy staff judge advocate for Spangdahlem Air Base, Germany. In this capacity, he serves as an international and criminal law advisor to United States Air Force units in Europe, Africa, and the Middle East. Major Kastenberg profusely thanks Professor Jonathan Drimmer, adjunct at Georgetown University Law Center, for his help and guidance and Allenby, Clementine, and Elizabeth Kastenberg for their help and support. The views and arguments supported in this article are those of the author's and not of any agency within the United States Government.

1. Black's Law Dictionary defines a fair and impartial trial as "[a] hearing by an impartial and disinterested tribunal; a proceeding which hears before it condemns, which proceeds upon inquiry, and renders judgment only after trial consideration or evidence and facts as a whole." BLACKS LAw DiCTIONARY, 596 6th ed. 1990. The dictionary cites Raney v. Commonwealth for the proposition that a fair trial is "one where the accuser's legal rights are safeguarded and respected." See, e.g., Sara Stapleton, Note: Ensuring a Fair Trial in the International Criminal Court: Statutory Interpretation and the Impermissibility of Derogation, 31 N.Y.U. J. INT'L \& POL. 535, 553 (1999) (quoting BLACKS LAW DICTIONARY, 596 6th ed. 1990). See also Irwin v. Dowd, 366 U.S. 717, 729 (1961). In his concurrence, Frankfurter wrote:

More than one student of society has expressed the view that not the least significant test of the quality of a civilization is its treatment of those charged with crime, particularly with offenses which arouse the passions of a community. One of the rightful boasts of Western civilization is that the State has the burden of establishing guilt solely on the basis of the evidence produced in court and under circumstances assuring an accused all the safeguards of a fair procedure.

Id. at 729 (Frankfurter, J., concurring). 
a defendant in a military commission since World War II. In the aftermath of 11 September 2001, such prosecution is inevitable. ${ }^{2}$ Although the rules of the military commission have yet to be tested, it is clear through the grant of defense counsel to accused persons, a right to zealous representation exists. ${ }^{3}$ Additionally, little scholarship has been devoted to the rights of defendants before various international tribunals.

This article serves two purposes. The first is to explore, and if possible, determine, what "international standards" exist regarding minimum levels of defense representation in international and war crimes tribunals. Military commissions are included in this latter category. The second purpose is to determine whether, in the current United States military commission scheme, defense counsel are expected to provide "adequate representation" within the requirements of both domestic and international law. In light of the second purpose, this paper will analyze proposed military defense counsel representation of persons accused of committing war crimes against the United States, as well as to suggest a framework that meets both international and domestic standards. Discussion of the right to effective defense counsel should be of growing importance for two reasons. First, there has been an international push toward accepting universal jurisdiction for the most heinous criminal offenses. ${ }^{4}$ Second, of domestic importance, proposed military commissions will place the tribunal system under both the potential review of the United

2. This proposal is found under the executive order and subsequent Department of Defense Directive (DoDD) which was created in response to the 11 September 2001 attack on the United States.

3. See DoD, Military Commission Order No. 1, section $4(b)(C)(2)$, which reads in pertinent part:

The Chief defense Counsel shall detail one or more Military Officers who are judge advocates of any United States armed force to conduct the defense for each case before a Commission (Detailed Defense Counsel). The duties of the detailed Defense Counsel are:

(a) To defend the Accused zealously within the bounds of the law without personal opinion as to the guilt of the Accused; and

(b) To represent the interests of the Accused in any review process as provided by the Order.

4. See, e.g., Bruce Broomhall, Towards the Development of an Effective System of Universal Jurisdiction for Crimes Under International Law, 35 NEW ENG. L. REV. 399, 400-02 (2001). See also Benard H. Oxman \& Luc Reydams, International Decision: Niyonteze v. Public Prosecutor, 96 AM. J. INT'L. L. 231 (2002). As an example of a recent exercise of universal jurisdiction, Switzerland prosecuted a former Rwandan mayor facing similar allegations as Akayesu. Niyonteze was found in Switzerland, and the Swiss government refused extradition to the ICTY and Rwandan national courts. Niyonteze was prosecuted under Swiss Military Law and sentenced to life in prison. However, on appeal, the Court d'Cassation dismissed some charges based on jurisdictional flaws and reassessed the sentence to fourteen years. Id. 
States Supreme Court, as well as "under the eye" of international organizations. ${ }^{5}$

This paper does not discuss the merits of military commissions versus civilian international or domestic courts. Nor does this paper directly address a variety of criticisms and questions regarding the composition, rules of evidence, or jurisdictional issues surrounding military tribunals. Where an issue regarding evidentiary rules, jurisdictional principles, appellate review, and tribunal composition arise in this paper, it only does so in the context of the role of the defense counsel. Finally, in many articles, writers fail to note the interplay between domestic and international law. This paper recognizes that United States constitutional law and common law tradition have great effect on international law. However, where the term international law is discussed and analyzed, the term is narrowly construed to apply only to current practice of international tribunals and agreements, as well as the development of a customary international law.

Finally, the courts of comparison in this paper, the ICTY and ICTR, are courts exercising universal jurisdiction. ${ }^{6}$ The contemplated military commissions are not an exercise in universal jurisdiction because the United States can be considered an injured party in some, if not all, cases. ${ }^{7}$ Yet, there are similar elements between courts exercising universal jurisdiction and the military commissions. For instance, the defendants in all cases can be reasonably said to have committed crimes against humanity. ${ }^{8}$ Likewise, there is an international interest in the procedure and outcome of each trial. Moreover, the use of comparative law is helpful in determining the fairness of any proceeding. To a degree, determinations of effectiveness of counsel are conducted by comparing a questionable case to established case law.

5. See, e.g., Amnesty International Press Release, 22 Mar. 2002. See also Article, "Taliban Prisoners Could Be Held for Decades," Yahoo News 13 Sept. 2002; Article, "Military Commissions Can't Compare to International Courts Due Process Standards Much Lower for Proposed U.S. Trials," Human Rights Watch release, Dec. 4, 2001.

6. Universal jurisdiction, defined in greater detail below, occurs where a state exercises jurisdiction over offenses to which it has no geographic, in-personam, or other nexus. See, e.g., James v. Illinois, 493 U.S. 307, 320 (1989) (Stevens, J., concurring); United States v. Smith, 680 F.2d 255, 257 (1st Cir. 1982) (citing United States v. Pizzarusso, 388 F.2d 8, 10-11 (2nd Cir. 1968), cert denied 392 U.S. 936 (1968)). See also RESTATEMENT (THIRD) OF FOREIGN RELATIONS LAW OF THE U.S.: JURISDICTION TO ADJUDICATE $§ 421$ (1986); S. Kobrick, The ex post facto Prohibition and the Exercise of Universal Jurisdiction Over International Crimes, 87 COLUMB. L. REV 1515 (1987).

7. The military commissions are basically operating under the internationally recognized theories of passive personal jurisdiction and territorial jurisdiction. See, e.g., IAN BROWNLIE, PrinCIPLES OF Public InTERnATIONAL LAw 303 (5th ed. 1998). See also Wade Esty, Note, The Five Bases of Extraterritorial Jurisdiction and the Failure of the Presumption Against Extratoriality, 21 HASTINGS INT'L \& COMP. L. REV 177, 182 (1997).

8. Crimes against humanity have been defined in a number of different instruments including the Geneva Convention for the Amelioration of the Condition of the Wounded and Sick in Armed Forcess in the Field, 75 U.N.T.S. 31 (Oct. 21, 1950); and Rome Sttue of the International Criminal Court, July 17, 1998, U.N. Doc. A/Conf. 183/9 [hereinafter ICC]. 
Few scholars of international law or criminal law dispute that a primary interest of a state is to prosecute criminals. Further, a primary purpose of a criminal court is its "truth-seeking function." However, this function does not occur without the constraints of a fair trial. Such constraints include, inter alia, a presumption of innocence, ${ }^{10}$ notice of criminality, ${ }^{11}$ formal evidentiary rules, ${ }^{12}$ a "beyond a reasonable doubt" burden of proof, ${ }^{13}$ the accused's right to an impartial judiciary, ${ }^{14}$ competent counsel, ${ }^{15}$ the right to face his or her

9. See, e.g., Swidler \& Berlin v. United States, 524 U.S. 399 (1998). See also James v. Illinois, 493 U.S. 307, 311 (1990).

10. See, e.g., ICTY Statute, art. 87(a); ICTR Statute, art. 87(a). Under Swiss Military Criminal Law, proof beyond a reasonable doubt is the lawful requisite to prove guilt. See, e.g., CPM, art. 5.

11. See, e.g., ICC Statute, art. 22, reiterating the customary international law principle of nullem crimen sine lege (no criminal responsibility unless the conduct was criminal at the time it took place). See also Smith v. Golden, 415 U.S. 566 (1974).

12. See, e.g., David Leonard, Perspectives on Proposed Federal Rules of Evidence $413-$ 415: The Federal Rules of Evidence and the Political Process, 22 FORDHAM L. J. 305, 310 (1995). Formal evidentiary rules exist to ensure the ordered flow of justice, free of surprise, and as a buffer against unreliable evidence. Rules also exist to protect areas of privacy customarily protected in common law. See, e.g., Robert J. Arujo, International Tribunals and Rules of Evidence: The Case for Respecting and Preserving the "Priest-Penitent" Privilege Under International Law, 15 AM. U. INT'LL. REV. 639 (2000). To date, the ICC, ICTR, and ICTY do not per se recognize such privileges.

13. Under customary international law, the burden of proof for guilt in trial appears to be the "beyond a reasonable doubt" standard enunciated in United States courts. See, e.g., ICTY, art. 87; ICTR, art. 87; and ICC, art. 66(3). Article 66 reads as follows:

Presumption if Innocence:

(3) In order to convict the accused, the Court must be convinced of the guilt of the accused beyond reasonable doubt.

Id.

14. For instance, the ICCPR provides:

In the determination of any criminal charge against him, or of his rights and obligations in a suit at law, everyone shall be entitled to a fair and public hearing by a competent, independent and impartial tribunal established by law.

ICCPR, art 14(1).

See, e.g., Tumey v. Ohio, 273 U.S. 510; 47 S. Ct. 437; 71 L. Ed. 749 (1927). See also, e.g., Piersack v. Belgium, 53 Eur. Ct. H.R. (ser. A) at 30 (1982) (European Court of Human Rights decreeing impartial judges as essential to justice). See also European Convention on Human Rights, art. 6 (1); art. 8(1) of the American Convention on Human Rights which provides:

Every person has the right to a hearing, with due guarantees and within a reasonable time, by a competent, independent, and impartial tribunal, previously established by law.

ACHR, art 8(1)

See also, e.g., Archibald Cox, The Independence of the Judiciary: History and Purposes, 21 DAYTON L. REV. 565, 568 (1996); Sam Ervin Jr., Separation of Powers: Judicial Independence, 35 LAW \& CONTEM. PROBS. 108, 121 (1970). Cox writes that the concept of an independent, impartial judiciary dates at least to Lord Coke's defense of common law judges against King James I in 1603, followed by the 1701 Act of Settlement protecting judges against undue influences from the crown. Id. at 568-70; Allen N. Sultan, Autonomy under International 
accusers,${ }^{16}$ and the right to present a complete defense. ${ }^{17}$ This article focuses on the right to effective counsel because, in theory, such counsel will ensure the presence of these other rights.

Part I of this article explores the evolution of legal rights accorded to enemy combatants under both treaty and customary international law. ${ }^{18}$ Additionally, this paper examines trials of international significance, such as the post World War II International Military Tribunals (IMT), for their impact on the right to counsel. These trials form part of the basis for current customary international law of such a right. Part II of this article addresses the meaning of "effective representation" as defined under international law. The ICTY and ICTR are compared and particular attention is paid to the ICTY case of Prosecutor $v$. Dusko Tadic, ${ }^{19}$ and the ICTR case of Prosecutor v. Jean Paul Akayesu. ${ }^{20}$ Both involve issues of attorney representation. Finally, Part II analyzes codes of defense counsel ethics and privileges between attorney and accused in each ad hoc tribunal. Part III of this article examines the Constitutional and common law right to effective assistance of counsel. While both the United States Constitution and common law principles bear significant impact on international understanding, this paper conducts a separate analysis is to ascertain whether the application of United States law as a guideline

Law, 21 Dayton L. Rev. 585, 590 (1996). Professor Sultan surveys the Roman, Greek, Hebrew, Islamic, and Christian legal traditions and concludes that the failure to provide an impartial judiciary rises to a jus cogens violation. Id. at 659 .

15. See, e.g., Convention III Relative to the Treatment of Prisoners of War, signed at Geneva 12 Aug. 1949, Art. 99, in DiETRICH SCHNIDLER AND JIRI TOMAN, THE LAWS OF ARMED CONFLICTS (1981), 355. See also, e.g., ICTR 96-4-T, I 66.

16. See, e.g., U.S. CONST. amend. VI. See also Lilly v. Virginia, 527 U.S. 116 (1999) (holding: In all criminal prosecutions, state as well as federal, the accused has a right, guaranteed by the Sixth and Fourteenth Amendments to the United States Constitution, "to be confronted with the witnesses against him." U.S. CoNST. amend. VI). See also Pointer v. Texas, 380 U.S. 400 (1965) (applying Sixth Amendment to the States).

The Court has also held, "The central concern of the Confrontation Clause is to ensure the reliability of the evidence against a criminal defendant by subjecting it to rigorous testing in the context of an adversary proceeding before the trier of fact." Maryland v. Craig, 497 U.S. 836,845 (1990).

It should be noted, that United States law places a higher threshold on the government than most other jurisdictions to show the right to confront witnesses as non absolute. Exceptions have been carved out for cases involving national security and child witnesses. See, e.g., id.; United States v. Yunis, 867 F.2d 617 (D.C. Cir. 1989). The ICTR, ICTY, and ICC permit adult witnesses to testify anonymously or via affidavit. See, e.g., The Prosecution v. Jean-Paul Akayesu, case no. ICTR-96-4-T, appeal of Akayesu.

17. For a discussion on the right to present a complete defense, see, e.g., United States v. Scheffer, 523 U.S. 303 (1998) (holding the right is not without limits and subject to rules of evidence).

18. Customary International Law is defined as "the unwritten body of rules or norms derived from the practice and opinion of states." Michael Byers, Terrorism, the Use of Force and International Law After 11 September, 51 INT'L \& COMP. L.Q. 401, 410 (2002).

19. Prosecutor v. Tadic, IT-94-1-T (1994).

20. Prosecutor v. Akayesu, ICTR 96-4-T (1998). 
meets international minimum standards. In this arena, this article considers the uniqueness of military representation is covered in regard to the meaning of effective representation of counsel. It should be noted that throughout this article, particularly in the sections involving United States law, the terms effective assistance and zealous representation are nearly synonymous. Part IV reviews the existing codes of ethics for military defense counsel as a guideline for ensuring effective and zealous representation. These codes are important because they establish expectations and parameters of representation. Finally, the article concludes with an assessment that, in terms of military defense counsel representation, the current military commission scheme meets or surpasses both international understandings and domestic legal standards.

\section{RIGHT TO COMPETENT COUNSEL UNDER INTERNATIONAL LAW}

A. Recognition of right to assistance of counsel in prisoner of war and war crimes cases, from 1863 to 1949: Creating the Customary International Law Basis.

Customary International law evolved from the common practices of states. ${ }^{21}$ One area of long term interest in customary international law concerns the treatment and rights of prisoners of war. Traditionally, the legal rights of enemy combatants were governed by principles affecting the treatment of prisoners of war. The concept of a military tribunal dates back roughly five hundred years. ${ }^{22}$ Prior to the United States Civil War, treatment accorded prisoners of war in Europe varied from conflict to conflict and from

21. BURNS WESTON ET AL., INTERNATIONAL LAW AND WORLD ORDER, 107 (3rd ed. 1997). Customary international law has also been described as, "uniformities in state behavior rather than formal writings." Id.

22. The first known attempt at establishing an international tribunal actually occurred in 1474. A trial of representative judges convicted Peter von Hagenbusch (also spelled Hagenbach), the Governor of Breisach, Austria for committing crimes against "God and man." See, e.g., Joel Cavicchia, The Prospects for an International Criminal Court in the 1990's, 10 DiCK. J. INT'L L. 223, 224 (1992). See also Timothy H.L. McCormack, Selective Reaction to Atrocity: War Crimes and the Development of International Criminal Law, 60 ALB. L. REV. 681 (1997); Daniel P. Pickard, Comment: Security Council Resolution 808, A Step Toward a Permanent International Court For the Prosecution of International Crimes and Human Rights Violators, 25 GOLDEN GATE U. L. REV. 435, 462 (1995).

Von Hagenbusch was tried before a tribunal of twenty-eight judges from the allied states of the Holy Roman Empire. While he was not tried for crimes committed during wars, this trial is significant in that he was stripped of his knighthood by an international tribunal which found him guilty of murder, rape, perjury, and other crimes against the law of God and man in the execution of a military occupation. Id. at 465 . 
warring state to warring state. ${ }^{23}$ However, there were expectations placed on both prisoners of war as well as states holding them. Interestingly, the first codified rules dealing with rights of prisoners of war arose during the United States Civil War. In 1863, the Union Army was issued General Order 100, also known as the "Lieber Code," after its author, Professor Francis Lieber of Columbia University. ${ }^{24}$ In all, the code contained 157 articles covering conduct norms for the Union Army. ${ }^{25}$ Articles 48 through 135 of this code dealt with the treatment and rights of prisoners of war. However, no specific article within this code guaranteed prisoners the right to assistance of counsel. Nonetheless, one article may be considered the basis for assuming the right to counsel at legal proceedings. Article 59 conferred jurisdiction over a prisoner for "crimes committed against the captor's army or people, committed before he was captured, and for which he had not been punished by his own authorities." ${ }^{26}$ Based on several military tribunals held during and immediately after the Civil War, it might also be the case that the right to counsel before such tribunals was assumed in the United States. ${ }^{27}$

Continental European laws, prior to 1865 , probably did not suppose a right to counsel inherent in prisoner of war cases. This is because the right to counsel did not exist in several of the central European legal systems during

23. See, e.g., Ralph M. Stein, Artillery Lends Dignity to What Otherwise Would Be a Common Brawl: An Essay on Post Modern Warfare and the Classification of Captured Adversaries, 14 PACE INT'L L. REV 133, 141-42 (2002). Stein analyzes treatment of prisoners of war based on the type of conflict. For instance, during the American War of Independence, treatment of captured Continental Army personnel was exceedingly harsh because British Army officers viewed the enemy as committing treason. In pre-Industrial Europe, prisoners were often given parole with the promise to not take up arms again in the conflict. Id. See also Alan Watson, Seventeenth Century Jurists, Roman Law, and the Law of Slavery, 68 CHI. KENT L. REV. 1343, 1350 (1993). Watson writes that Grotius accepted that prisoners of war and their descendants could become slaves. However, this was an arbitrary practice.

24. Prepared by Francis Lieber, promulgated as General Order No. 100 by President Lincoln, 24 Apr. 1863.

25. The Lieber Code gave recognition to the universality of certain offenses such as rape, robbery, fraud, burglary, forgery, and murder. See also L.C. Greene, Enforcement of Law in International and Non-International Conflicts, the Way Ahead, 24 DENV J. INT'L L. \& POL'Y 285, 296 (1995).

26. General Order No. 100, supra note 24, art. 59.

27. See, e.g., William Winthrop, MilitaRy LaW and PRECEDENTS 832-42 (1920). Winthrop writes:

But as a general rule, and as the only quite safe and satisfactory course for rendering of justice to both parties, a military commission will-like a court martial-permit and pass upon objections interposed to members, as indicated in the 88th Article of war, will formally arraign the prisoner, allow attendance of counsel, entertain special pleas if any are offered. Id. at 841 .

However, the quality of defense counsel during these early military commissions is not without reasoned criticism. See, e.g., Carol Chomsky, The United States-Dakota War Trials: A Study in Military Injustice, 43 STAN. L. REV. 13 (1990). 
the middle of the 19 th century. ${ }^{28}$ Yet, European governments in the latter half of that century expressed increasing concern over the rights of prisoners held by combatant states. ${ }^{29}$ This concern was partly a product of demographic changes in military service. With the dual advent of industrialism and the growth of empires, a dramatic increase in the size of "citizen armies" occurred. ${ }^{30}$ Additionally, the Third Republic in France was a driving force in expanding the right to representation in criminal courts. ${ }^{31}$

In 1874, on the initiative of Czar Alexander II of Russia, delegates from fifteen European states met in conference in Brussels to discuss codifying rules of warfare. ${ }^{32}$ During this conference, a text was finalized which again dealt, in part, with prisoners' rights. ${ }^{33}$ The text was composed of fifty-six Articles. Article 28 read, in part, "Prisoners of war are subject to the laws and regulations in force in the army whose power they are." While Article $28 \mathrm{did}$ not confer a right to counsel before a disciplinary or judicial hearing, it suggested that an accused facing such a hearing would be accorded some legal or statutory rights based on the captor state's laws. Furthermore, as a result of political changes, by 1878 , several states in Western Europe recognized a right to counsel. ${ }^{34}$ In 1880 , the Institute of International Law, a British-based association, published a text titled, "The Laws of War on Land." 35 The text itself was comprised of eighty-six articles and provisions dealing with legal rights of prisoners of war. For example, Article 62 stated "prisoners are subject to the laws and regulations in force in the army of the enemy." 36 As with the Brussels Conference, this article did not confer a right to counsel but suggested a prisoner suspected of criminal misconduct should be accorded the principal rights conferred under captor state law. The importance of this text,

28. See, e.g., The hon. Robert W. Sweet, Civil Gideon \& Confidence in a Just Society, 17 YALE L. \& POL'Y REV. 503, 504 (1998) (citing Earl Johnson, Jr. Toward Equal Justice: Where the United States Lands Two Decades After, 5 MD. J. CONTEMP. LEGAL IsSUES 199, 205 (1994)); Justice Sweet writes that France and Germany provided a right to counsel in the 1870's. See also John Leubsdorf, On the History of French Legal Ethics, 8 UNIV. CHI. SCHL. ROUNDTABLE 341(2001). Leubsdorf writes that independence from the government was an important feature of French defense counsel (avocats) as early as the Napoleonic era. However, the right to counsel for all persons accused of crimes did not appear under law until the Third republic after 1870. See also W.E. Butler, Civil Rights in Russia, 1, 7, in CIVIL RIGHTS IN IMPERIAL RuSSIA (Olga Crisp \& Linda Edmondson eds., 1989). Butler notes that trial by jury did not exist until granted by statute in 1864 . However, it was not until the provisional government of Kerensky in 1917 that right to counsel appears. Id.

29. DieTrich SCHNIDLER \& JIRI TOMAN, THE LAWS OF ARMED CONFLICTS 27 (1981).

30. S.E. FINER, HISTORY OF GOVERNMENT, VOL III 1625-30 (1997).

31. Sweet, supra note 28, at 504.

32. SCHINDLER \& TOMAN, supra note 29, at 27.

33. Id. The Final Protocol was signed on 27 August 1874 by the following states: Austria-Hungary, Belgium, Denmark, France, Germany, Great Britain, Greece, Italy, Netherlands, Portugal, Russia, Spain, Sweden and Norway, Switzerland, Turkey. Id.

34. See, e.g., Sweet, supra note 28 , at 504.

35. SCHINDLER \& TOMAN, supra note 29 , at 35.

36. Id. 
along with the 1874 Brussels Conference was that both were incorporated into the Hague Conventions of $1899^{37}$ and $1907 .^{38}$ However, neither of those Conventions provided specific rights to counsel for prisoners before judicial or disciplinary proceedings.

The watershed years of World War I (1914-1918) showed deficiencies in prior conventions and codes regarding conduct of war in general. Post-war concepts of international law changed dramatically as a result of the gross bloodshed in that conflict. ${ }^{39}$ Views toward treatment of prisoners of war, in particular, underwent significant changes. This change was partly due to heavily propagandized and celebrated cases such as the German execution of a British Nurse accused for spying. ${ }^{40}$ Moreover, there were significant instances of trials in prisoner of war camps where an accused's legal rights were non-existent, even by contemporary standards. ${ }^{41}$ Credible accounts of life in German prisoner of war camps reveal that enlisted men often received brutal treatment while incarcerated. ${ }^{42}$ As a result of these events, national leaders and private humanitarian organizations attempted to provide an international code of rights for prisoner of war treatment. These attempts reached fruition in 1929 in Geneva, Switzerland. ${ }^{43}$

The 1929 Geneva Convention first codified the right of prisoners of war to defense representation in judicial proceedings. This Convention occurred as a result of pressure applied by the International Red Cross beginning in $1921 .^{44}$ The 1929 Convention consisted of ninety-seven articles concerning the treatment of prisoners of war. It reiterated a recurring theme of combatant state jurisdiction over prisoners. ${ }^{45}$ It also provided for the establishment of military tribunals modeled on the same basis as the combatant state's

37. See International Convention With Respect to the Laws and Customs of War by Land (Hague I), signed at the Hague July 29, 1899.

38. See International Convention Concerning the Laws and Customs of War on Land (Hague II), signed at the Hague, Oct. 18, 1907.

39. See, e.g., FINER, supra note 30, at 1630-32. See also B.H.LIDDELL-HART, A HISTORY OF THE FIRST WORLD WAR (1972).

40. At the outbreak of World War I, the German Government established a military bureau of investigation to "determine violations of the laws and customs of war which enemy military and civilian persons have committed against the Prussian troops. Nurse Edith Cavell, a British citizen, had been trapped behind German lines in Belgium after that country's invasion. While working as a nurse she assisted stranded allied troops in making their way back to France "to fight again." She was captured and, after nine weeks in solitary confinement, confessed to this activity. After a short trial, and despite a protest from the United States legation in Brussels, she was executed by firing squad. See, e.g., Greene, supra note 25, at 305.

41. Id. See also NEIL M. HeYMAN, DAILY LIFE DURING WORLD WAR I 141 (2002).

42. Id.

43. Convention Relative to the Treatment of Prisoners of War, 27 July 1929, in SCHINDLER \& TOMAN, supra note 29, at 271.

44. $I d$.

45. Id. art. 45. This Article states in part: "prisoners of war shall be subject to the laws, regulations, and orders in force in the armed forces of the detaining Power ...." 
tribunals. ${ }^{46}$ However, the Convention went further than any predecessor when it stated, "no prisoner of war shall be sentenced without the opportunity to first defend himself." 47 Most important for the purposes of this paper is Article 62 which read, "The prisoner of war shall have the right to be assisted by a qualified advocate of his own choice ...." That article further established a right for the "protecting power" to procure an advocate for the prisoner. ${ }^{48}$ Moreover it placed an obligation on the "detaining power" if requested by the "protecting power," to provide a list of persons qualified to conduct the defense. ${ }^{49}$ Article 63 provided a basic guarantee to prisoners of war, that any prisoner prosecution would mirror the existing procedure applicable to persons in the armed force of the detaining power. ${ }^{50}$ Article 64 further guaranteed this right through an additional right of appeal, presumably before the captor state's appellate courts. ${ }^{51}$

Just as World War I provided a watershed in the evolution of international law, so too did World War II (1939-1945). That war proved equal in its devastation to all prior wars and ill-treatment accorded both prisoners and civilians, particularly by the Axis powers, caused the issue of prisoner rights to be renewed once more. ${ }^{52}$ From the conclusion of hostilities until 1949 a series of discussions concerning treatment of prisoners of war culminated in what became known as the Third Geneva Convention of 1949 (Geneva III). ${ }^{53}$ Geneva III supplemented the 1929 Geneva Convention by expanding, rather than abrogating, prisoner of war legal rights before judicial and tribunal hearings. These rights are found in Article 82 through Article 108. One significant clarification from the 1929 Convention dealt with trial forum. For instance, in the 1929 Convention, there was no specific rule enumerating forum. In Geneva III, Article 84 permitted a prisoner of war "to be tried before a military court, unless the detaining power's laws permit a prisoner to be tried before a civil court." 54 Likewise, in Geneva III, clarification was provided regarding the quality of defense counsel. Article 99 of Geneva III states, "[N]o prisoner of war may be convicted without having had an opportunity to present his defence and the assistance of a qualified advocate or counsel." "55 While it may seem that this language is

46. Id. art. 46.

47. Id. art. 61.

48. Id. art. 62.

49. $l d$. art. 62.

50. Id. art. 63.

51. Id. art. 64.

52. SCHINDLER \& TOMAN, supra note 29 , at 195.

53. Geneva Convention Relative to the Treatment of Prisoners of War, Aug. 12, 1949, 6 U.S.T. 3316, 75 U.N.T.S. 135, in SCHINDLER \& TOMAN, supra note 29, at 355.

54. Id. art. 84.

55. Id. art. 99. 
taken directly from the 1929 Convention, discussion at Geneva III helped define what "qualified advocate or counsel meant."

Equally important in setting international standards for rights to counsel were the post-war "Nuremberg trials" of German war criminals. As the war ended, allied representatives met in London to conclude a charter detailing the "constitution, jurisdiction and functions of the International Military Tribunal (IMT), which conducted the Nuremberg trials. ${ }^{57}$ At these trials, all accused persons were afforded defense counsel. ${ }^{58}$ As a counterpart to the IMT in Europe, an International Military Tribunal was created in Asia to address war crimes by Japanese military officers and political leaders. ${ }^{59}$ Again, all accused persons were afforded defense counsel. One difference between the IMT for Asia and the Nuremburg trials had to do with selection of counsel. Most of the Japanese defendants were provided military officers with legal billets (JAGS) ${ }^{60}$ In the most salient of these cases, In re Yamashita, military defense counsel vigorously pursued General Yamashita's appeal to the Supreme Court. ${ }^{61}$ While, Yamashita does not formally create any new parameters for defense counsel in war crimes tribunals, it does create a standard for defense counsel representation. This standard, as discussed below, is one of zealous representation through all legitimate and ethical means.

In one respect, primarily because of concerns from the lead American Prosecutor, Supreme Court Justice Robert Jackson, the concept of fairness

56. See, e.g., Ruth Wedgwood, Agora, Military Commissions: Al-Qaeda, Terrorism, and Military Commissions, 96 A.J.I.L. 328, 337 (2002).

57. See Charter of the International Military Tribunal (IMT). Agreement for the Prosecution and Punishment of the Major War Criminals of the European Axis (London Agreement), Aug. 5, 1945, 58 Stat. 1544, 82 U.N.T.S. 280. In the course of World War II, the Allied Governments issued several declarations concerning the punishment of war criminals. On 7 October 1942, it was announced that a United Nations War Crimes Commission would be set up for the investigation of war crimes. It was not, however, until 20 October 1943, that the actual establishment of the Commission took place. In the Moscow Declaration of 30 October 1943, the United States, United Kingdom, and Soviet Union issued a joint statement that the German war criminals should be judged and punished in the countries in which their crimes were committed, but that, "the major criminals whose offenses have no particular geographic localization," would be punished "by the joint decision of the Governments of the Allies." See SCHNINDLER \& TOMAN, supra note 29, at 881.

58. IMT, sect. IV provides the right to counsel.

59. The International Military Tribunal for the Far East was established by a special proclamation of General Douglas MacArthur as the Supreme Commander in the Far East for the Allied Powers. See SCHNINDLER \& TOMAN, supra note 29, at 881.

60. See, e.g., George F. Guy, The Defense of Yamashita, 6 USAFA J. LEG. STUD. 215, 216-17 (1996).

61. See, e.g., Yamashita, 327 U.S. 1, 5 (1946). The court held, "Throughout the proceedings which followed, including those before this Court, defense counsel have demonstrated their professional skill and resourcefulness and their proper zeal for the defense with which they were charged." Id. 
came to the forefront of the IMT. ${ }^{62}$ However, even before Justice Jackson became involved in the case, rules concerning the rights of accused persons before the tribunal were promulgated. ${ }^{63}$ By 1945 standards, the rules reflected more of Constitutional and common law rights than those practiced in the Soviet Union. ${ }^{64}$ In establishing procedural rules of law that involved the right to competent counsel as part of the right to a fair trial, the IMT formed a standard from which later international trials could not deviate.

The history of prisoner of war rights reveals a customary international law basis for requiring effective representation at war crimes tribunals. While there is a large corpus of domestic law from criminal trials, the addition of a customary international law analysis is important to war crimes trials and military commissions in that it provides guidance for minimum standards of representation. That some scholars may argue Sixth Amendment protections may not apply to military commissions makes the customary international law

62. Jackson's opening statement highlighted the importance of fairness before the IMT: Before I discuss the particulars of the evidence, some general considerations which may affect the credit of this trial in the eyes of the world should be candidly faced. There is a dramatic disparity between the circumstances of the accusers and the accused that might discredit our work if we should falter in even minor matters .... We must never forget that the record on which we judge these defendants is the record on which history will judge us tomorrow. To pass these defendants a poisoned chalice is to put it to our lips as well. We must summon such detachment and intellectual integrity to our task that this Trial will commend itself to posterity as fulfilling humanity's aspiration to do justice.

Stapleton, supra note 1, at 545.

63. The IMT Rules regarding Fair Trial are found in Section IV of the London Charter. This section reads as follows:

Section IV: Fair Trial for Defendants

Article 16. In order to ensure a fair trial for the Defendants, the following procedure shall be followed:

(a) The Indictment shall include full particulars specifying in detail the charges against the Defendants. A copy of the Indictment and of all the documents lodged with the Indictment, translated into a language which he understands, shall be furnished to the Defendant at a reasonable time before the trial.

(b) During any preliminary examination or trial of a Defendant he shall have the right to give any explanation relevant to the charges made against him.

(c) A preliminary examination of a Defendant and his Trial shall be conducted in, or translated into, a language which the Defendant understands.

(d) A Defendant shall have the right to conduct his own defense before the Tribunal or shall have the assistance of Counsel.

(e) A Defendant shall have the right through himself or through his Counsel to present evidence at the Trial in support of his defense, and to cross examine any witness called by the Prosecution. (828).

Id. 
study all the more important. This is because the Geneva Convention III regarding prisoners of war is a partially self-executing document. ${ }^{65}$

\section{B. Current Views of an Accused's Basic Right to Competent Counsel Under International Law and Universal Jurisdiction: Other General} Sources

While the right to competent counsel and universal jurisdiction are two different areas of study, the two are related. As noted above, courts exercising universal jurisdiction are adjudicating the most heinous offenses. Under contemporary legal standards, defendants facing trial are entitled to competent counsel.

\section{Right to Competent Counsel}

The right to competent counsel under international law is essentially a subset of the right to a fair trial. While the Constitutional right to competent counsel governs in any U.S. criminal court, international tribunals represent a special area for review of international standards. Such a review is partly an exercise in reading the plain language of conventions and agreements. In part, a review of standards is also a study in comparative jurisprudence. This is because most tribunals consist of a prosecution of foreign defendants for offenses committed outside the territory of the prosecuting state or body. Offenses constituting war crimes, crimes against humanity, genocide, and offenses violating "the law of nations" often do not have a geographic nexus to the prosecuting state or body. However, jurisdiction is obtained because such crimes are viewed as victimizing humanity. ${ }^{66}$ Yet, there is almost global

65. See, e.g., United States v. Noriega, 808 F. Supp 791, 798 (S.D. Fla. 1992). In Noriega, the District Court acknowledged the difficulty in determining the elements of a selfexecuting treaty. However, it held:

In the case of Geneva III, however, it is inconsistent with both the language and spirit of the treaty and with our professed support of its purpose to find that the rights established therein cannot be enforced by the individual POW in a court of law. After all, the ultimate goal of Geneva III is to ensure humane treatment of POWs-not to create some amorphous, unenforceable code of honor among the signatory nations. It must not be forgotten that the Conventions have been drawn up first and foremost to protect individuals, and not to serve State interests.

Id. at 1532-35.

Also of importance, the District Court earlier viewed Article 22 as providing a right of access to defense counsel. Id. See also, e.g., Michael McKenzie, Recent Development, Treaty Enforcement in U.S. Courts, 34 HARV. INT'L L.J. 596 (1993).

66. See, e.g., Susan Chesterman, An Altogether Different Order: Defining the Elements of Crimes Against Humanity, 10 DUKE J. COMP. \& INT'L L. 307 (2000). 
recognition that even the most heinous actors are accorded the right of a competent counsel. ${ }^{67}$

International also law recognizes the authority of a nation to try war criminals by military commission. ${ }^{68}$ As noted earlier, military courts have been used to trying violators of laws of war since before the Civil War. However, other than Geneva III, little discussion exists regarding either the right to a fair trial and effective assistance of counsel before military tribunals. There are, however, two international understandings that bear on the general concept of a fair trial for all persons, the Universal Declaration of Human Rights (UDHR) ${ }^{69}$ and the ICCPR. ${ }^{70}$ Additionally, there are regional agreements which recognize the right to counsel, such as The American Convention on Human Rights, ${ }^{71}$ The European Charter on Human Rights, ${ }^{72}$

67. Stapleton, supra note 1 , at 539.

68. See, e.g., Major Timothy MacDonald, Military Commissions and Courts Martial: A Brief Discussion of the Constitutional and Jurisdictional Distinctions Between the Two Courts, Army Law 19 (2002). See also Oxman \& Reydams, supra note 4, at 235.

69. G.A. Res. 217A (III), U.N. GAOR, 3d Sess., at 71, U.N. Doc. A/810 (1948).

70. ICCPR, supra note 14. The preamble of the ICCPR states the purpose of the Covenant, including the statement that "recognition of the inherent dignity and of the equal and inalienable rights of all members of the human family is the foundation of freedom, justice and peace in the world" and that "these rights derive from the inherent dignity of the human person." Id. For a brief summary of the history of the ICCPR, see David P. Stewart, United States Ratification of the Covenant on Civil and Political Rights: The Significance of the Reservations, Understandings and Declarations, 42 DEPAUL L. REV. 1183 (1993).

71. ACHR, supra note 14. See, e.g., ACHR art. 8(2)(d); art. 8(2)(e), which reads in full:

(d) the right of the accused to defend himself personally or to be assisted by legal counsel of his own choosing, and to communicate freely and privately with his counsel;

(e) the inalienable right to be assisted by counsel provided by the state, paid or not as the domestic law provides, if the accused does not defend himself personally or engage his own counsel within the time period established by law.

ld.

72. See, e.g., Charter of Fundamental Rights of the European Union, Dec. 7, 2000, 2000 O.J. (C 364) 1, art. 47 [hereinafter Charter of Fundamental Rights]. Article 47 reads, in part:

Everyone is entitled to a fair and public hearing within a reasonable time by an independent and impartial tribunal previously established by law. Everyone shall have the possibility of being advised, defended and represented.

Id.

This Charter is different than the earlier 1950 European Convention for the Protection of Human Rights and Fundamental Freedoms, codified at Nov. 4, 1950, 312 UNTS 221. In the European Convention, art. 6 provides the right to a fair trial. The right to counsel is enumerated at Article 6(3)(c) which reads:

(c) to defend himself in person or through legal assistance of his own choosing or, if he has not sufficient means to pay for legal assistance, to be given it free when the interests of justice so require.

Id. 
and the African Charter on Human and People's Rights, ${ }^{73}$ all of which recognize a right to counsel as part of the right to a fair trial. ${ }^{74}$ Of course, while these regional agreements may reflect customary international law, like the ICCPR, they have no legal effect on American courts. ${ }^{75}$ Additionally, while neither the ICCPR, UDHR, nor the regional agreements specifically address fair trials for military prisoners, all are influential in their universality.

As noted above, the UDHR envisions a fair trial for all accused persons. While the UDHR is an aspirational document, rather than binding law, it is central to the goal of achieving universal justice. ${ }^{76}$ There are two articles within the UDHR that directly bear on the right to a fair trial. Article 10 enumerates the right to a "fair and public hearing by an independent and impartial tribunal ... of any criminal charge against him." "77 Likewise, Article 11 enumerates the right to a presumption of innocence, a prohibition against false imprisonment, as well as a protection from unjust punishment. ${ }^{78}$

The ICCPR, on the other hand, is the primary international law guarantor of the international right to a fair trial. ${ }^{79}$ Initially opened for state signature in 1966, it is composed of fifty-one articles and covers a wide array of basic individual rights such as freedom of religion, liberty of movement, privacy rights, and the right to a fair trial. ${ }^{80}$ The United States signed the ICCPR on September 8, 1992. ${ }^{81}$ Under Article 14, an accused is provided the "minimum guarantee" of the right to be tried in his own presence. ${ }^{82}$ Additionally the same article guarantees an accused person both the right to legal assistance

73. African [Banjul] Charter on Human Peoples Rights, June 27, 1981, 21 I.L.M. 58 (1982) [hereinafter African Charter]. See, e.g., art. 7(1)(c) which reads in full:

(c) the right to defence, including the right to be defended by counsel of his choice.

Id.

74. Id. art. 47. Article 47, in part, reads: Everyone is entitled to a fair and public hearing within a reasonable time by an independent and impartial tribunal previously established by law. Everyone shall have the possibility of being advised, defended and represented. Id.

75. See, e.g., United States v. Duarte-Acero, 296 F.3d 1277 (11th Cir. 2002). See also Hain v. Gibson, 287 F.3d 1224 (10th Cir. 2002).

76. See, e.g., A Eide et al. eds., The Universal Declaration of Human Rights: A Commentary (1992). The UDHR is not a treaty. It was adopted by the United Nations General Assembly as a resolution having no force of law. Its purpose, according to its preamble is to provide a "common understanding" of human rights and fundamental freedoms.

77. Universal Declaration of Human Rights, art. 10.

78. Id. art. 11.

79. See, e.g., Stewart, supra note 70 , at 1 .

80. Id.

81. Id. Stewart notes that generally existing United States law complies with the ICCPR. Most of the individual rights and freedoms guaranteed by the United States Constitution and state constitutions are embodied in the ICCPR. Id.

82. Art. 14(3)(d). 
and to be informed of this right. ${ }^{83}$ Moreover, an accused is entitled to have legal assistance without payment where the accused is indigent. ${ }^{84}$

\section{Universal Jurisdiction}

It is important to note that much of war crimes and crimes against humanity prosecution that relies on customary international law is conducted in courts exercising universal jurisdiction. Therefore, it is incumbent to gain an understanding of universal jurisdiction and defense practice in these courts. However, as noted in the introduction, United States military commissions are not courts of universal jurisdiction. The commissions do share similar features, to courts exercising universal jurisdiction.

Universal jurisdiction occurs where a state exercises jurisdiction over offenses to which it has no geographic, in-personam, or other nexus. ${ }^{85}$ Offenses targeted for universal jurisdiction typically involve war crimes, crimes against humanity, or other jus cogens offenses. ${ }^{86}$ Courts exercising universal jurisdiction are rare. Most national courts deny jurisdiction over crimes that have no geographic or personal nexus to them. However, where a court exercises universal jurisdiction, greater scrutiny should be given to its employment of due process (or the right to a fair trial).

Some scholars conclude universal jurisdiction fills a gap where other, more basic doctrines of jurisdiction, provide no basis for national proceedings. ${ }^{87}$ Universal jurisdiction occurs where a state exercises jurisdiction over criminal offenses regardless of whether any party to the offense, or the offense itself, has a geographic nexus to the state. Often universal jurisdiction is confused with a state's exercise of its "long arm" jurisdiction over offenders. ${ }^{88}$

83. Id.

84. Id.

85. See, e.g., James v. Illinois, 493 U.S. 307, 320 (1989) (Stevens, J., concurring).

86. Jus cogens has been defined as "peremptory norms of general international law." Vienna Convention on the Law of Treaties, May 23, 1969, art. 53, U.N. Doc. A/Conf. 39/27, 8 I.L.M. 679, 699. The Vienna Convention describes these norms as ones "accepted and recognized by the international community of States as a whole as a norm from which no derogation is permitted and which can be modified only by a subsequent norm of general international law having the same character." Id. The Restatement (Third) of International Law provides that a state violates $j u s$ cogens if it "practices, encourages, or condones (a) genocide, (b) slavery or slave trade, (c) the murder or causing the disappearance of individuals, (d) torture or other cruel, inhuman, or degrading treatment or punishment, (e) prolonged arbitrary detention, (f) systematic racial discrimination, or (g) a consistent pattern of gross violations of internationally recognized human rights." THE RESTATEMENT (THIRD) OF INTERNATIONAL LAW $\S 702$.

87. See, e.g., Bruce Broomhall, Symposium: Towards the Development of an Effective System of Universal Jurisdiction for Crimes Under International Law, 35 NEW ENG. L. REV 339,400 (2001).

88. Id. 
However, universal jurisdiction may be seen as an evolutionary growth of the "long-arm" jurisdictional exercise over crimes.

As World War II ended, allied representatives met in London to conclude a charter detailing the "constitution, jurisdiction and functions of the International Military Tribunal (IMT), which conducted the Nuremberg trials." 89 The concept of universal jurisdiction for certain offenses gained initial acceptance through the IMT, and the International Military Tribunals for Asia, ${ }^{90}$ as well as the 1968 Israeli trial of Adolph Eichmann. ${ }^{91}$ Indeed, universal jurisdiction concepts developed in the Eichmann trial have been accepted by other national or state courts. For example, in the 1989 Ontario High Court of Justice case, Regina v. Finta, ${ }^{92}$ a Canadian court accepted the principle that state courts can exercise criminal law jurisdiction "with respect

89. See Agreement for the Prosecution and Punishment of the Major War Criminals of the European Axis Powers and the Charter of the International Military Tribunal, Aug. 8, 1945, 59 Stat. 1544, 82 U.N.T.S. 279. In the course of World War II, the Allied Governments issued several declarations concerning the punishment of war criminals. On 7 October 1942, it was announced that a United Nations War Crimes Commission would be set up for the investigation of war crimes. It was not, however, until 20 October 1943, that the actual establishment of the Commission took place. In the Moscow Declaration of 30 October 1943, the United States, United Kingdom, and Soviet Union issued a joint statement that the German war criminals should be judged and punished in the countries in which their crimes were committed, but that, "the major criminals whose offenses have no particular geographic localization," would be punished "by the joint decision of the Governments of the Allies." See SCHINDLER \& TOMAN, supra note 29 , at 881 .

90. Id. at 881 . The International Military Tribunal for the Far East was established by a special proclamation of General Douglas MacArthur as the Supreme Commander in the Far East for the Allied Powers. Id. See also Henry T. King, Jr., Universal Jurisdiction: Myths, Realities, War Crimes and Crimes Against Humanity: The Nuremberg Precedent, 35 NEW ENG. L. REV. 281, 283 (2001). Professor King writes:

In today's world, universal jurisdiction is a vital legacy of Nuremberg. We should never forget that until Nuremberg it was only national courts that could prosecute criminals for crimes committed in that particular country. This concept was bypassed by Nuremberg when it obliterated traditional aspects of national sovereignty in its approach towards crimes against peace and war crimes and when it articulated for the first time the concept of crimes against humanity.

Id.

91. State of Israel v. Eichmann, Criminal case No. 46/61 (36 I.L.R. 5 (J.M.DC 1968)). In Eichmann, the court recognized universal jurisdiction to prosecute an offense against the Jewish people that occurred prior to the formation of the State of Israel. The court specifically held:

The State of Israel's "right to punish," the Accused derives, in our view, from two cumulative sources: a universal source (pertaining to the whole of mankind) which vests the right to prosecute and punish crimes of this order in every state within the family of nations; and a specific or national source which gives the victim nation the right to try any who assault its existence. Id. $\mathbb{I} 30$.

92. See, e.g., Regina v. Finta, 1 S.C.R 701 (1994). 
to acts which occurred outside its territory." $" 93$ In the field of tort law, the United States exercises universal jurisdiction for some claims through the Alien Tort Statute. ${ }^{94}$ These trials also added to the growing acceptance that some offenses, such as genocide, constitute crimes against humanity that can be prosecuted at any location by any recognized court complying with basic procedural rights.

Additionally, international instruments exist which recognize the efficacy of universal jurisdiction. For instance, the 1949 Geneva Conventions grant universal jurisdiction on the part of all nations to prosecute alleged perpetrators of "grave breeches of those conventions." 95 The Geneva Convention obliges a state that is not prepared to prosecute a bona fide crime against humanity to hand over the suspect to another state prepared to prosecute. $^{96}$ Likewise, International Covenant on Civil and Political Rights (ICCPR $)^{97}$ appears to give some recognition of universal jurisdiction in Article 15(b). ${ }^{98}$

Jurisdiction for jus cogens offenses such as war crimes has been established for the ad hoc international tribunals involving Yugoslavia and Rwanda, as well as the International Criminal Court. National courts, however, have increasingly taken the lead in prosecuting foreigners for

93. Id. (quoting the Permanent Court of International Justice in the Steamship Lotus (1927)).

It does not, however, follow that international law prohibits a state from exercising jurisdiction in its own territory, in respect of any case which relates to acts which have taken place abroad, and in which it cannot rely on some permissive rule of international law. Such a rule would only be tenable if international law contained a general prohibition in states to extend the application of their laws and the jurisdiction of their courts to persons, property and acts outside their territory.

Id.

94. 28 U.S.C. 1350 et seq. See also Doe v. Unocal, 2002 WL 31063976 (9th Cir 2002); Kadic v. Karadzic, 70 F.3d 232 (2nd Cir. 1995); Filartega v. Pena Irala, 630 F.2d 876 (2d Cir 1980).

95. See Geneva Convention for the Amelioration of the Condition of the Wounded and Sick in the Armed Forces in the Field, Aug. 12, 1949, 6 U.S.T. 3114, 75 U.N.T.S. 31 (1950); Geneva Convention for the Amelioration of the Condition of Wounded, Sick, and Shipwrecked Members of Armed Forces at Sea, Aug. 12, 1949, 6 U.S.T. 3217, 75 U.N.T.S. 85, entered into force Oct. 21, 1950; Geneva Convention Relative to the Treatment of Prisoners of War, Aug. 12, 1949, 6 U.S.T. 3316, 75 U.N.T.S. 135; Geneva Convention Relative to the Protection of Civilian Persons in Time of War, Aug. 12, 1949, 6 U.S.T. 3516, 75 U.N.T.S. 28, entered into force Oct. 21, 1950. See also King, supra note 90, at 283.

96. Id.

97. ICCPR, supra note 14.

98. ICCPR, supra note 14 , art. 15 (b), $\S 2$ reads as follows:

Nothing in this article shall prejudice the trial and punishment of any person for any act or omission which at the time it was committed, was criminal according to the general principles of the law recognized by the community of nations. 
international crimes committed outside of their borders. ${ }^{99}$ Prior to 1999 , several other countries exercised jurisdiction over crimes for which there was no geographic or nationality nexus. For instance, in 1991, Australia prosecuted a Ukranian immigrant for crimes he committed against specific Jews during World War $\Pi{ }^{100}$ Likewise, Belgium has asserted universal jurisdiction over war crimes and crimes against humanity. ${ }^{101}$ Spain has argued before the British courts for jurisdiction over General Augusto Pinochet based on atrocities committed during his tenure as president of Argentina. ${ }^{102}$ And, the Netherlands has attempted to obtain jurisdiction over persons accused of crimes against humanity in its former colony, Suriname. ${ }^{103}$ Each of these states possess advanced legal systems considered to embody the procedural and substantive rights contemplated in international law, as discussed below. However, none of these states utilized a military court in their prosecution attempts.

In one instance, however, a state has utilized a military court to prosecute a civilian for war crimes. In 1999, Switzerland prosecuted a former Rwandan mayor for his role in the 1994 genocide. ${ }^{104}$ In Prosecutor $v$. Niyonteze, ${ }^{105}$ the accused was prosecuted before a court consisting of five military officers, the president sitting as both judge and jury member. ${ }^{106}$

99. Leila Nadya Sadat, Redefining Universal Jurisdiction, 35 NEw. ENG. L. REV. 241, 243 (2001) (quoting Theodore Meron, Is International Law Moving Towards Criminalization?, 9 EUR. J. INT'L L. 18 (1988)).

100. Polyukhovich v. The Commonwealth (1991), 172 C.L.R. 501 (Austl.).

101. See, e.g., Luc Reydams, International Decisions: Belgian Tribunal of First Instance of Brussels (Investigating Magistrate), 93 AM. J. INT'L L. 700, 703 (1999) (finding universal jurisdiction over crimes against humanity, under customary international law and jus cogens, in case involving criminal complaints against Chile's General Pinochet).

102. National Tribunal, Criminal Chamber in Plenary, Appellate no. 173/98 first section, sumario 1/98, Order, Madrid, 5 Nov. 1998 (confirming Spanish jurisdiction to try former Chilean head of state Augusto Pinochet for genocide, including torture, and terrorism committed against Spanish nationals in Chile). See, e.g., Ex Parte Pinochet, Appeal, 24 Mar. 1999.

103. See, e.g., Douglass Cassel, Empowering United States Courts to Hear Crimes Within the Jurisdiction of the International Criminal Court, 35 NEW. ENG. LAW REV. 421, 426 f.n. 19 (2001) (citing Court Amsterdam, Order of Nov. 20, 2000 (Bouterse case), available at $<$ <ttp://www.rechtspraak.nl/gerechtshof/amsterdam> (last visited Feb. 17, 2001)); Marlise Simons, Dutch Court Orders an Investigation of ' 82 Killings in Suriname, N.Y. TIMES, Nov. 26,2000 , at A12. The Dutch Court found jurisdiction to investigate torture leading to death, allegedly committed by former Surinamese military leader Desi Bouterse against Surinamese citizens in Suriname, based on a retrospective application of the 1989 Dutch statute implementing the Convention Against Torture.

104. See, e.g., Oxman \& Reydams, supra note 4, at 235.

105. See, e.g., Niyonteze v. Public Prosecutor (Trib. militaire de cassation Apr. 27, 2001).

106. Id. See also Oxman \& Reydams, supra note 4, at 233-34. (Niyonteze was convicted of murder, incitement to commit murder, genocide, and incitement to commit genocide. He was sentenced to life in prison. However, on appeal his conviction for murder was overturned for jurisdictional reasons. After reassessment for the war crimes conviction, he was sentenced to fourteen years followed by a ten year expulsion from Switzerland.) Id. 
Switzerland's military code, developed in 1927, provided jurisdiction over any defendant for war crimes. ${ }^{107}$ Thus, in Switzerland, a foreign civilian can be prosecuted before a military court for heinous war crimes offenses.

\section{II: RIGHT TO A FAIR TRIAL AND COMPETENT COUNSEL IN INTERNATIONAL PRACTICE}

Having established that a right to counsel exists in treaties, customary international law, and historic precedent, it becomes important to analyze how this right has been recognized and implemented by judicial bodies. The international ad hoc tribunals are perhaps the best examples because of their universality. This is not to suggest either tribunal has unlimited jurisdiction. To the contrary, the jurisdiction is limited to subject matter, time period, and geographic region.

\section{A. Basic Review on Implementation of Tribunals, ICTY \& ICTR:}

The Charter of the United Nations (U.N. Charter) governs the implementation of universal international criminal law jurisdiction. ${ }^{108}$ Chapter VII of the Charter defines what applicable response or action the United Nations will pursue in regard to "threats against, or breaches of, the peace, as well as acts of aggression." ${ }^{09}$ Article 39 of the U.N. Charter places the onus of determining whether a threat to peace and security exists. ${ }^{110}$ Additionally, the Security Council is charged with the role of deciding what measures "shall be taken in accordance ... to maintain or restore international peace and security." Since 1990, the Security Council has exercised criminal law jurisdiction in establishing two ad hoc tribunals, the ICTY and ICTR. To date, neither tribunal has run its course of prosecuting accused persons deemed to have committed crimes against humanity or other heinous offenses.

The tribunals are similar in their construction. However, there are slight differences in the jurisdictional reach of each ad hoc tribunal. ${ }^{11}$ Each has a

107. See, e.g., Code Penal MilitaIRE, SuISSE (1927) art. 2. Article 2 provides: "Those subject to military law are . . . (9.) Civilians who, in the event of armed conflict, commit violations of international law. Jurisdiction extends whether a declared war or other armed conflict is in existence." Id. art. 108. Moreover, jurisdiction is conferred wherever a violation of the laws or customs of war occurs. Id. art. 109.

108. See, e.g., Stewart, supra note 81, at 1 .

109. U.N. Charter, Ch. VII, titled, 'Action With Respect To Threats To The Peace, Breaches Of The Peace, And Acts Of Aggression.'

110. U.N. Charter art. 39.

111. The jurisdiction of the ICTY and ICTR is limited to crimes in the former Yugoslavia, Rwanda, and its neighboring states. ICTY Statute, supra note 10, art. 8 ("The territorial jurisdiction of the International Tribunal shall extend to the territory of the former Socialist Federal Republic of Yugoslavia ... ."); ICTR Statute, supra note 10, art. 7 ("The territorial jurisdiction of the International Tribunal for Rwanda shall extend to the territory of Rwanda... as well as to the territory of neighbouring States in respect of serious violations of international 
trial chamber, a chief prosecutor, an appeals chamber, and a registry. In each, the registry is, in part, de facto responsible for ensuring the procedural rights of the accused. This is because each registry is tasked with maintaining a list of available defense counsel and assigning such counsel when the need arises. Although neither tribunal constitutes a "military commission," the international nature of the tribunal, coupled with its jurisdiction arising from acts of war, presents a standard to compare the proposed military commissions. Likewise, it is important to note the severity of the offenses as well as the historic background of each jurisdiction. The background history highlights the severity of the offenses against the individuals accused as well as presents the right to effective counsel in a proper context.

\section{B. International Tribunal for Rwanda (ICTR)}

Between April and July 1994 somewhere between 500,000 and over one million persons belonging to a distinct ethnic group were executed by Rwandan government forces, their intermediaries, and supporters. ${ }^{112}$ Individuals considered by the United Nations (U.N.) Security Council to be the perpetrators or main participants of this genocide were ultimately indicted and, in an ongoing process, brought to trial before an ad hoc tribunal specifically created to punish those offenders under international law. ${ }^{113}$

Understanding the historic background to the Rwandan genocide is also imperative to analyzing Akayesu's trial, both from a perspective of universal jurisdiction and due process.

Prior to 1994, Rwanda was the most densely populated country in Africa. ${ }^{114}$ From 1897 until 1917 most of its territory was ruled by Germany through a colonial administration. ${ }^{115}$ From 1917 through its eventual independence, Rwanda was governed by Belgium through a mandate granted by the League of Nations. ${ }^{116}$ The Belgian colonial administration in its African territories such as Rwanda promoted a descending superiority of white

humanitarian law committed by Rwandan citizens."). The ICTR's temporal jurisdiction extends only to crimes committed during 1994. Id. But see ICTY Statute, supra note 10, art. 8 (temporal jurisdiction commences January 1, 1991, but no ending date given).

112. ICTR-96-4-T, $\mathbb{I} 111$.

113. Id.

114. Id.

115. See, e.g., Robert F. Van Lierop, Report on the International Criminal Tribunal for Rwanda, 3 HOFSTRA L. \& POL'Y SYMPOSIUM 203, 207-08 (1999). Van Leirop argues that German and later Belgian colonial authorities drove the distinction between Hutu and Tutsi to even further prominence. Id. This argument appears to have been adopted by the ICTR in several trial chamber decisions. See also RICHARD F. NYROP ET AL., RWANDA, A COUNTRY STUDY 11-13 (1982).

116. NYROP ET AL., supra note 115. 
Europeans and then stratified other classes accordingly. ${ }^{117}$ This stratification formed the basis for decades of post-colonial upheaval. ${ }^{118}$ The colonial administration was also responsible for repression and other human rights violations. ${ }^{119}$ Belgian colonial authorities vested a minority indigenous ethnic group, the Tutsi, with substantial benefits which were deprived to the majority ethnicity, the Hutu. ${ }^{120}$ Indeed the authorities recognized a Tutsi monarchy, subservient to Belgian authority, but above that of any Hutu form of government. ${ }^{121}$ In 1956, the United Nations Trusteeship Council directed Belgium to organize elections on the basis of universal suffrage. ${ }^{122}$ Essentially four political parties were largely formed on ethnic lines. ${ }^{123}$ As a result of these elections, the Hutu gained a political majority. ${ }^{124}$ From November 1959 until 18 October 1960, a series of ethnic-based attacks, reprisals, and counterreprisals occurred between the Hutu's majority party and the Tutsi minority. ${ }^{125}$ On that later date, Belgian authorities established an autonomous provisional government headed by Gregoire Kayibanda, the Hutu head of the majority Hutu party (MDR). ${ }^{126}$ In turn, a large population of Tutsi, including the monarchy, fled to neighboring countries. ${ }^{27}$ Accordingly, these groups became known as "exiles." 128

117. See, e.g., Peter Uvin, On counting, categorizing, and violence in Burundi and Rwanda, 148, 149-50, in CENSUS AND IDENTITY: THE POLITICS OF RACE, ETHNICITY, AND LANGUAGE IN NATIONAL CENSUS (Kertzer \& Arel eds., 2002). The five categories of race from descending order were: Europeans, "Mulattos" referring to children of white males and African females, Asians, Tutsi (labeled as "blacks not submitted to customary chiefs"), and Hutu (labeled as "indigenous"). Id.

118. Id.

119. Id.

120. ICTR -96-4-T, 9 82-84. According to evidence from a prosecution expert, Dr. Alison De Forges, the population percentages in 1930 were composed as follows: $84 \%$ Hutu, $15 \%$ Tutsi, and $1 \%$ Twa. As of 1930 , every Rwandan was required to carry an identification certificate and be identified as a member of either ethnic group. Apparently this practice continued after Rwandan independence and lasted until 1994. Id.

121. Id.

122. Id. 187.

123. Id. II 88. The four parties were the Parmehutu (MDR); the Union Nationale Rwandaise (UNAR), a party comprised of Tutsi "monarchists"; the Aprosoma, a predominately Hutu group; and the Rassemblement Democratique Rwandais (RADER), a combination of Hutu and Tutsi moderates. Id.

124. Id.

125. Id. See also Jose Alvarez, Crimes of State/Crimes of Hate: Lessons from Rwanda, 24 YALE J. INT'LL. 365, 389 (1999); Uvin, supra note 117, at 153. Professor Uvin writes that in early 1962 more than 2000 Tutsi were killed, and the following year, more than 10,000 . Over 40,000 fled $R$ wanda in 1963. Id.

126. ICTR 96-4-T, 988.

127. Id. See also NYROP ET AL., supra note 115 , at 17.

128. ICTR 96-4-T, I 88. See also Ogenga Otunnu, Rwandese Refugees and Immigrants in Uganda, 3, 5-7, in THE PATH OF A GENOCIDE: THE RWANDA CRISIS FROM UgANDA TO ZAIRE (Howard Adelman \& Astri Suhrke eds., 1999). Some of the Tutsi exiles were employed by Idi Amin's regime in the Ugandan military and death squads. Amin actively supported the exile's incursions into Rwanda. Id. at 14-15. 
After Rwandan independence was declared on July 1, 1962, the MDR became the sole governing party under Kayibanda. ${ }^{129}$ While large numbers of Tutsi fled Rwanda, some of the population remained behind. ${ }^{130}$ Moreover, some groups that had fled launched armed incursions into Rwanda, destabilizing its economy. ${ }^{131}$ By 1973, Rwanda was.wracked by internal unrest. This unrest, coupled with the Tutsi incursions, caused Kayibanda's government's collapse. ${ }^{132}$ His successor, General Juvenal Habyarimana, achieved power by armed force and had several opposition and political leaders imprisoned and executed, including the former president. ${ }^{133}$

In 1975 Habyarimana instituted a one-party system under his party the Mouvement revolutionanaire national pour le developpement (MRND). ${ }^{134}$ At first, Habyarimana's government did not present itself as anti-Tutsi, but by 1980 , with a continually weakening economy and internal dissension, the government became anti-Tutsi. ${ }^{135}$ On 1 October 1990 Tutsi exiles in Uganda launched a failed attack in Rwanda. ${ }^{136}$ The MNRD government's response to this attack included the arrest of thousands of opposition members, mainly Tutsi, in Rwanda. ${ }^{137}$ However, some internal and international pressure remained so that Habyarimana was pressured into political multi-party recognition. ${ }^{138}$ Furthermore, his government agreed to accept political reforms. ${ }^{139}$ This action did not stop Tutsi incursions into Rwanda because the government remained unwilling to accept the free return of all exiles. ${ }^{140}$

As a result of the government's intransigence toward the Tutsi exiles (RPF), their political organization's military wing, the Rwandan Patriotic Army (RPA), launched a large-scale attack on Rwanda on 1 October 1991..$^{141}$ From that time, until a cease-fire agreement in July 1992, Tutsi exile forces and the Hutu dominated Rwandan military engaged in open warfare. ${ }^{142}$ That cease-fire accepted the RPF into Rwandan politics, but ultimately this

129. ICTR 96-4-T, $\mathbb{1} 88$.

130. Id.

131. Id. at 89.

132. Id.

133. Id.

134. Id. II 92.

135. ICTR 96-4-T, II 93. The government began systematically discriminating against Tutsi by establishing quotas in universities, government employment, and services. Additionally, Hutu from Habyiramana's native regions, Gisenyi, and Ruhengeri were given preference.

136. Id.

137. Id. The Tutsi forces were joined under the aegis of a new political group, the Rwandan Patriotic Front (RPF), composed mainly of Tutsi exiles in Uganda.

138. Id.

139. Id. See also Alvarez, supra note 125 , at 389

140. ICTR 96-4-T, 995.

141. Id.

142. Id. 
acceptance did not stem the RPA from continuing to attack Hutu targets. ${ }^{143}$ As a result, Hutu political groups grew increasingly anti-Tutsi and drew a harder-line toward the Tutsi than Habyarimana. ${ }^{144}$ Radio stations, for example, transmitted anti-Tutsi propaganda. ${ }^{145}$ However, a break in the fighting appeared when both parties agreed to settle disputes by signing parts of peace accords created in Arusha. ${ }^{146}$ Yet, during this time, Tutsi soldiers in neighboring Burundi, executed the Hutu president of that country resulting in Habyarimana making contradictory public statements both about the peaceaccords and the Tutsi in general. ${ }^{147}$ However, he agreed publicly to implement the Arusha peace accords. ${ }^{148}$ Then, on April 6, 1994, while returning from a trip in Dar-es-Salaam, Tanzania, he and the new Burundi president were killed when their aircraft crashed in Rwanda. ${ }^{149}$ Although the cause of the crash was not immediately determined, blame was quickly placed on the RPA.

On April 7, 1994, throughout parts of the country, the Presidential Guard and Hutu militia (called interhamwe) began killing Tutsi as well as moderate Hutu. ${ }^{150}$ Some of these victims, such as the president of the Rwandan Supreme Court, represented the best chance to avert genocide. ${ }^{151}$ Additionally, the Rwandan Armed Forces executed ten United Nations troops. ${ }^{152}$ In quickly erected detention centers and in the open, a wholesale slaughter of civilians occurred on a scale unprecedented since 1945. Unlike the highly systematized "final solution" of the Nazi genocide program, the Rwandan genocide stemmed from a largely unplanned popular uprising. ${ }^{153}$ In

143. Id.

144. Id. 2000)

145. See, e.g., Prosecutor v. Ruggiu, No. ICTR-97-32-I (Judgment and Sentence; June 1,

146. ICTR 96-4-T, 995.

147. Id.

148. Id.

149. Id.

150. Id. See also Alvarez, supra note 125, at 389. Interhamwe stands for "those who stand together." Id. (citing PHILIP GOUREVITCH, WE WISH TO INFORM YOUTHAT TOMORROW WE WUL BE KILLED WITH OUR FAMILIES 93 (1989)). According to Alvarez, the Interhamwe were armed by French agents. Additionally, these French agents were in control of Rwandan counterinsurgency operations.

151. ICTR 96-4-T, 995.

152. Id. See Alvarez, supra note 125, at 390 . Alvarez writes that after the execution of the ten Belgian soldiers, the U.N. peacekeeping forces abandoned Rwanda. The Security Council eventually permitted French troops into the area. However, the French were accused, with some evidence, of defending the genocide's perpetrators. Id.

153. Although persecutions and murders of Jews occurred in Germany prior to its invasion of Poland in 1939, the "final solution" was designed at the Wansee conference held on January 20,1942 at a villa in the Berlin suburb of Wansee to coordinate the activities of German government agencies in developing Zyklon-B gas, crematoria, and dedicated death camps for the "final solution." The Wansee Conference was convened by Gestapo chief and SS Commander Reinhard Heydrich, the head of the Reich Security Main Office (RHSA), who indicated to the conference that "in the course of this Final Solution of the European Jewish problem approximately eleven million Jews are involved" - to be worked to death or killed 
several cases, political leaders of prefectures and towns (communes) became the local "movers and shakers" of the genocide. ${ }^{154}$

\section{Governing Statutes relevant to the ICTR selection of defense counsel:}

The ICTR was established by the United Nations Security Council in Resolution 955 on 08 November 1994. ${ }^{155}$ In Resolution 955, the Security Council concluded the situation in Rwanda "constituted a threat to international peace and security within the meaning of Chapter VII of the U.N. Charter." 156 As a result, it established an ad-hoc tribunal for prosecuting persons committing genocide, crimes against humanity, and violations of Article 3 common to the Geneva Convention and of Additional Protocol III. ${ }^{157}$

outright. XIII Trials of War Criminals before the Nuremberg Military Tribunals 210-19 (Nuremberg Document No. NG-2586-G), in WILLIAM L. SHIRER, THE RISE AND FALL OF THE THIRD REICH: A HISTORY OF NAZI GERMANY (Simon \& Shcuster, Inc., 1960) (1959).

154. See, e.g., Cecile E.M. Meijer, The War Crimes Research Office Presents: News from the International Criminal Tribunals, 9 Hum. Rts. Br. 30, 33-34 (2002). In addition to Akayesu, the ICTR charged Ignace Baglishema for war crimes. He was the bourgmestre of the Mabanza commune. See Case No. ICTR 95-1A-T.

155. See, e.g., S.C. res. 955, U.N. SCOR. 3453rd mtg., U.N. Doc. S/RES/955 (1994). [hereinafter Resolution 955].

156. Id.

157. See Resolution 955, supra note 155, art. 1. Articles 1 through 4 read as follows:

Article 1: Competence of the International Tribunal for Rwanda. The International Tribunal for Rwanda shall have the power to prosecute persons responsible for serious violations of international humanitarian law committed in the territory of Rwanda and Rwandan citizens responsible for such violations committed in the neighboring States between 1 January 1994 and 31 December 1994 , in accordance with the provisions of the present Statute.

Article 2: Genocide

1. The International Tribunal for Rwanda shall have the power to prosecute persons committing genocide as defined in paragraph 2 of this article or of committing any of the other acts enumerated in paragraph 3 of this article.

2. Genocide means any of the following acts committed with intent to destroy, in whole or in part, a national, ethnical, racial, or religious group, as such:

a) Killing members of the group;

b) Causing bodily or mental harm to members of the group;

c) Deliberately inflicting on the group conditions of life calculated to bring about its physical destruction in whole or in part;

d) Imposing measures intended to prevent births within the group;

e) Forcibly transferring children of the group to another group.

3. The following acts shall be punishable:

a) Genocide;

b) Conspiracy to commit genocide;

c) Direct and public incitement to commit genocide;

d) Attempt to commit genocide;

e) Complicity in genocide.

Article 3: Crimes against Humanity: The International Tribunal for $R$ wanda shall have the power to prosecute persons responsible for the following crimes when committed as part of a widespread or systematic attack against any civilian population on national, political, ethnic, racial, or religious grounds: 
Rules governing the ICTR were promulgated on October 1, 1994 by the Security Council. These rules are found in the Annex to Resolution $955 .{ }^{158}$ The ICTR rules govern jurisdiction, trial and appellate procedure, selection and qualification of judges, recognized defenses, prosecution, organization of the ICTR, rules of evidence and procedure, and other important matters outside the scope of this paper.

For the purpose of defense counsel selection, two Articles within the Rules play a direct role. First, Article 16 establishes a Registry. ${ }^{159}$ This Registry provides and determines available defense counsel. ${ }^{160}$ Second,
a) Murder;
b) Extermination
c) Enslavement;
d) Deportation;
e) Imprisonment;
f) Torture;
g) Rape;
h) Persecutions on political, racial and religious grounds;
i) Other inhumane acts.

Article 4: Violations of Article 3 common to the Geneva Convention and of Additional Protocol II: The International Tribunal for Rwanda shall have the power to prosecute persons committing or ordering to be committed serious violations of Article 3 common to the Geneva Conventions of 12 August 1949 for the Protection of War Victims, and of Additional Protocol II thereto of 8 June 1977. These violations shall include, but shall not be limited to:
a) Violence to life, health and physical or mental well-being of persons, in particular murder as well as cruel treatment such as torture, mutilation or any form of corporal punishment;
b) Collective punishments;
c) Taking of hostages;
d) Acts of terrorism;
e) Outrages upon personal dignity, in particular humiliating and degrading treatment, rape, enforced prostitution, and any form of indecent assault;
f) Pillage;
g) The passing of sentences and the carrying out of executions without previous judgment pronounced by a regularly constituted court, affording all the judicial guarantees which are recognized as indispensable by civilized peoples;
h) Threats to commit any of the foregoing acts.

158. Id.

159. Article 16 reads as follows:

The Registry shall be responsible for the administration and servicing of the International Tribunal for Rwanda.

1. The Registry shall consist of a Registrar and other such staff as may be required.

2. The Registrar shall be appointed by the Secretary-General after consultation with the President of the International Tribunal for Rwanda. He or she shall serve a four year term and be eligible for re-appointment. The terms and conditions of service of the Registrar shall be those of an Assistant Secretary-General of the United Nations.

3. The staff of the Registry shall be appointed by the Secretary General on the recommendation of the Registrar.

160. See Directive on the Assignment of Defence Counsel, Jan. 91996. 
Article 20 lists the accused's rights. These rights include a presumption of innocence, ${ }^{161}$ equality of all persons at the tribunal, ${ }^{162}$ and the right against forced testimony. ${ }^{163}$ In terms of defense counsel, the accused is entitled "to have adequate time and facilities for the preparation of his or her defence and to communicate with counsel of his or her own choosing."164 The accused is further guaranteed this right through the language, "to be tried in his or her presence, and defend himself or herself in person or through legal assistance of his or her own choosing ... and to have legal assistance assigned to him or her in any such case if he or she does not have sufficient means to pay for it." 165

Moreover, other articles such as Article 2 of the Registry confers the right to counsel on any person suspected of crimes within ICTR or national court jurisdiction. Article 4 provides counsel to indigent persons, while Articles 6 though 12 provide procedural steps for defining and declaring indigence, as well as appealing an adverse finding. Article 13 governs prerequisites for assignment of counsel. Under Article 13 any person may be assigned as counsel if the Registrar concludes: the attorney has been admitted to practice law in a State, or is a professor of law at a university or similar institution and has at least ten years of relevant experience. ${ }^{166}$ Further, the attorney must speak either French of English. ${ }^{167}$ These qualifications, not found in the ICTY, provide a greater, albeit still minimum, guarantee not found in the ICTY.

Finally, ethics guidance to defense counsel is found in the ICTR Code of Professional Conduct for Defence Counsel (ICTR ethics code). ${ }^{168}$ The ICTR ethics code was promulgated on 8 June 1998. The ICTR code is premised on the belief that counsel "must maintain high standards of professional conduct." 169 It also requires counsel to "act honestly, fairly, skillfully, diligently and courageously." "170 The ICTR rules further acknowledge the defense counsel's "overriding duty to defend their client's interests, to the extent that they can do so without acting dishonestly or by improperly prejudicing the administration of justice."171

The ICTR ethics code is directly relevant to the dual concepts of the right to counsel and the right to a fair trial. It enumerates the scope and termination

161. See Resolution 955, supra note 155 , art. 20(3).

162. Id. art. 20(1).

163. Id. art. $20(4)(\mathrm{g})$.

164. Id. art. $20(4)(\mathrm{b})$.

165. Id. art. $20(4)(\mathrm{d})$.

166. See Resolution 955, supra note 155 , art. 20(4)(5).

167. Id.

168. ICTR Code of Professional Conduct For Defence Counsel (1998) [hereinafter ICTR ethics code].

169. ICTR Code Annex, (1) ICTR ethics code, annex. $\mathbb{I} 1$.

170. Id. $\Psi(2)$.

171. Id. $\mathbb{I}(3)$. 
of representation, ${ }^{172}$ the competence and independence of defense counsel, ${ }^{173}$ expectations of diligence, ${ }^{174}$ client communication, ${ }^{175}$ and confi-dentiality. ${ }^{176}$ Furthermore, the ICTR ethics code enumerates prohibited conflicts of interest, ${ }^{177}$ candor toward the tribunal, ${ }^{178}$ and duties to other witnesses. ${ }^{179}$ Finally, the ICTR code cautions defense counsel against misconduct. ${ }^{180}$ How the ICTR rules and codes governing defense counsel works in practice is best seen through one of the completed trials, where significant representation issues were raised on appeal.

172. Id. at Article 4: Article 4 reads:

(1) Counsel must advise and represent their client until the client duly terminates Counsel's position, or Counsel is otherwise withdrawn with the consent of the Tribunal.

(2) When representing a client, Counsel must:

(a) Abide by a client's decisions concerning the objectives of representation if not inconsistent with Counsel's ethical duties; and,

(b) Consult with the client about the means by which those objectives are to be pursued.

(3) Counsel must not advise or assist a client to engage in conduct which Counsel knows is in breach of the Statute, the Rules, or this Code, and, where Counsel has been assigned to the client, the Directive.

Id.

173. Id. art. 5. Article 5 reads:

In providing representation to a client, Counsel must:

(a) Act with competence, dignity, skill, care, honesty, and loyalty;

(b) Exercise independent professional judgment and render open and honest advice.

(c) Never be influenced by improper or patently dishonest behavior on the part of a client.

(d) Preserve their own integrity and that of the legal profession as a whole;

(e) Never permit their independence, integrity and standards to be compromised by external pressures.

ICTR Ethics Code, annex, art. 6.

174. Id. art. 6: Article 6 reads:

Counsel must represent a client diligently in order to protect the client's best interests. Unless the representation is terminated, Counsel must carry through to conclusion all matters undertaken for a client within the scope of his legal profession. Id.

175. Id. art. 7.

176. Id art. 8. A client confidence may be revealed under limited circumstances. These circumstances include client consent, voluntary disclosure to a third party, to establish a defense against a specific charge by the client against the Counsel, and to prevent further criminal activity. Id.

177. Id.

178. Id. art. 9.

179. Id. art. 13.

180. Id. art. 17-18. 


\section{Case Example: Prosecutor v. Jean-Paul Akayesu ${ }^{181}$}

\section{A. Background Charges and Underlying Offenses:}

During the Rwandan Genocide, Jean-Paul Akayesu served as the bourgmestre (mayor) of the Taba Commune. ${ }^{182}$ This was an appointed, rather than elected, position. ${ }^{183}$ In this capacity, he was responsible for maintaining law and public order. ${ }^{184}$ The trial court found that at least 2000 Tutsi's were killed between 7 April and June 1994. The trial court characterized the killings in Taba, as "openly committed and so widespread that, as bourgmestre, [Akayesu] must have known about them." 185 The court further held, "although he had the authority and responsibility to do so, [Akayesu] never attempted to prevent the killing of Tutsis in the commune in any way or called for assistance from regional or national authorities to quell the violence."186

Akayesu's role in the charged offenses was not merely passive acquiescence. Several beatings, murders, and sexual degradations occurred at and near his place of work. ${ }^{187}$ Moreover, on at least one occasion he participated in ferreting out Tutsis and suspected Tutsi sympathizers in house to house searches. ${ }^{188} \mathrm{He}$ further ordered the beatings of Tutsis to obtain intelligence and ordered the local militia to kill several others. ${ }^{189}$ On April 19, 1994, Akayesu ordered the Hutu residents of Taba to kill intellectual and influential people. ${ }^{190}$ Based on these instructions, five secondary school teachers were hacked to death by locals wielding machetes and agricultural implements. ${ }^{191}$ On several other occasions, he personally used threats of death and torture to obtain information on the whereabouts of Tutsi intellectuals. ${ }^{192}$

Akayesu was originally charged under several specifications of genocide, crimes against humanity, and violations of Article 3 Common to the Geneva Conventions and of Article 4(2)(e) of Additional Protocol 2. ${ }^{193}$ With

181. Case No. ICTR-96-4-T.

182. Id. $\ 10$.

183. Id.

184. Id. 112.

185. Id.

186. Id. The court further listed specific offenses which Akayesu took part in or encouraged. Id.

187. Id.

188. Id.

189. Id.

190. Case No. ICTR-96-4-T \20.

191. Id.

192. Id.

193. ICTR 96-4-T (Sentencing): Akayesu was specifically charged as follows:

Count 1: Genocide, punishable by Article 2(3)(a);

Count 2: Complicity in Genocide, punishable by Article 2(3)(e);

Count 3: Crimes Against Humanity (extermination), punishable by Article 3(b);

Count 4: Direct and Public Incitement to Commit Genocide, punishable by 
in the ambit of each, he was specifically charged with murder, torture, rape, incitement to commit genocide, cruel treatment, and other inhumane acts. During trial, the prosecution was permitted to amend its indictment and add the crime of rape under the aegis of genocide and crimes against humanity. ${ }^{194}$ The tribunal convicted him of genocide, direct and public incitement to commit genocide, and crimes against humanity. ${ }^{195}$ At several occasions during the trial and subsequent appeals, Akayesu expressed dissatisfaction with his defense counsel. ${ }^{196}$

\section{B. The Trial and Appellate Chamber's Decisions Regarding the Right to Competent Counsel}

Akayesu raised several "fair trial" issues both during trial and on appeal. Important to the analysis in this paper was Akyesu's dual claim of the tribunal denying him his choice of counsel, as well as ineffective assistance of counsel. ${ }^{197}$ Initially, Akayesu argued his inability to afford a counsel. The

Article 2(3)(c);

Count 5: Crimes Against Humanity, punishable by Article 3(a);

Count 6: Violations of Article 3 Common to the Geneva Conventions as incorporated by Article 4(a);

Count 7: Crimes Against Humanity, punishable by Article 3(a) of the Statute of the Tribunal;

Count 8: Violations of Article 3 Common to the Geneva Conventions as incorporated by Article 4(a);

Count 9: Crimes Against Humanity (murder) punishable by Article 3(a) of the Statute of the Tribunal;

Count 10: Violations of Article 3 Common to the Geneva Conventions as incorporated by Article 4(a);

Count 11: Crimes Against Humanity (torture) punishable by Article 3(f);

Count 12: Violations of Article 3 Common to the Geneva Conventions as incorporated by Article 4(a);

Count 13: Crimes Against Humanity (rape), punishable by Article 3(g);

Count 14: Crimes Against Humanity (other inhumane acts), punishable by Article 3(i); Count 15: Violations of Article 3 Common to the Geneva Conventions and of Article 4(2)(e) of Additional Protocol 2 (outrages upon personal dignity, in particular rape, degrading and humiliating treatment and indecent assault).

Id.

194. Id.

195. Id.

196. Id.

197. See ICTR-96-4-T, Decision Concerning a Replacement of an Assigned Defense Counsel and Postponement of the Trial, 31 October 1996 [hereinafter Replacement of Defense Council]. See also Annex B, Akayesu's Grounds of Appeal. In his second notice of appeal, Akayesu charged:

The Court and the registrar deprived the Appellant of [his] right to choose his Defence Counsel. He could not have his first choice, Johan Scheers because ... the Registrar's Office. On 31 October 1996, Michael Karnavas, Mr. Scheers' assistant who had contacted Scheers in Belgium, illegally coerced the Appellant to "choose" him as defence Counsel in replacement of Mr. Scheers. The Appel- 
Tribunal found Akayesu indigent, and in accordance with the Directive on Assignment of Defense Counsel, the Registrar of the Tribunal assigned a Western European attorney, Mr. Johan Scheers, as his defense counsel. ${ }^{198}$ However, Mr. Scheers absented himself from the tribunal due to financial disagreements with the tribunal and the Tribunal then found Scheers' unavailable. ${ }^{199}$ Akayesu was then appointed Michael Karnavas as his new defense counsel. ${ }^{200}$ This substitution occurred on October 31, 1996 and it resulted in a scheduled delay of trial until January $9,1997 .{ }^{201}$ However, on November 20 , 1996 Akayesu requested a further change in defense counsel. ${ }^{202} \mathrm{He}$ specifically requested a Canadian attorney named Mr. Michael Marchand. ${ }^{203}$ The Tribunal denied this request and on January 9, 1997 the Registrar appointed, over Akayesu's objection, Mr. Nicolas Tinagaye and Mr. Patrice Monthe to defend Akayesu. ${ }^{204}$ Akayesu then attempted to represent himself. ${ }^{205}$ However, the Tribunal did not permit this, and kept Tiangaye and Monthe in their capacity as his defense counsel. ${ }^{206}$

On appeal, Akayesu contended that in denying him his choice of counsel, the Tribunal denied him the right to a fair trial. ${ }^{207} \mathrm{He}$ further com-

lant dropped Michael Karnavas because of his deceitful maneuvers. Moreover, it has been discovered that Karnavas had been a candidate to work as Prosecutor and that he has already written and stated that he could never defend a "genocider."

Id. art. (2d)(a).

198. See Replacement of Defense Counsel, supra note 197.

199. Id.

200. Id.

201. Id.

202. Id.

203. Annex B, Akayesu's Grounds of Appeal. In his second notice of appeal, Akayesu complained:

Appellant's second choice was Mr. Marchand from Montreal, Canada, who was present at the opening of his trial on 9 January 1997. The prosecutor knew he was present as recognized . . . in the New York Times on 8 September 1998. The Court and the Registrar illegally refused requests by Mr. Marchand to address the Court and meet his client.

Id. art. (2d)(a).

It appears, however, that Akayesu's arguments were contrary to the Tribunal's understanding. The Tribunal asserted it denied Mr. Marchand because Akayesu was already represented. Therefore, if Akayesu desired Marchand, he would have to be represented by Marchand pro bono. Marchand found this requirement untenable. Moreover, at the time of Akayesu's request, Mr. Marchand's credentials could not be verified by the trial chamber. See, e.g., Appellate Chamber Judgment, Akayesu's Ground of Appeal 951.

204. Annex B, Akayesu's Grounds of Appeal A(2d)(a); Appellate Chamber Judgment, Akayesu's Ground of Appeal, $145-48$.

205. See Appellate Chamber Judgment, Akayesu's Grant of Appeal, I 49.

206. Id. 950 .

207. See id. 
plained of ineffective assistance of counsel. ${ }^{208}$ In response to these claims, the Appeals Chamber held that an indigent person's right to counsel of his own choosing raised an issue of balancing that right against ensuring "proper use of the Tribunal's resources." 209 Moreover, the Appellate Chamber held "in principle, the right to free legal assistance of counsel does not confer the right to counsel of ones own choosing."210 To the Appeals Chamber, the right to choose a specific counsel applies only to an accused who can afford to pay for counsel. ${ }^{211}$ That Chamber found it compelling that Akayesu was permitted to release counsel on two separate occasions. ${ }^{212}$ In terms of not permitting Akayesu the right to defend himself, the Appeals Chamber noted that at several occasions "his attitude toward the [Trial] Chamber suggested otherwise."213

In determining whether Tiangaye and Monthe were competent counsel, the Appeals Chamber noted that the ICTR standard of review is "gross incompetence." 214 As a starting point, the Appeals Chamber presumes counsel is competent. $^{215}$ This presumption places a burden of proof on the defendant. In order to establish "gross incompetence," an accused would have to demonstrate, there is "reasonable doubt as to whether a miscarriage of justice resulted."216 In establishing this standard, the Appeals Chamber considered

208. See, e.g., Annex B, Akayesu's Grounds of Appeal. The underlying basis for this complaint involved several factors. First, neither defense counsel contacted Mr. Scheers for his prior case-work and advice, despite the fact Akayesu gave both counsel permission. Second, the defense counsel called as an expert witness General Romeo Dallaire, the United Nations commander who testified that a genocide had taken place. Third, Akayesu alleged his defense counsel disclosed privileged statements. Fourth, Akayesu charged that his attorneys made no effort to secure expert assistance to rebut the Prosecution's main expert, Dr. Alison DeForges. Fifth, Akayesu averred his defense counsel failed to probe for bias against any of the Prosecution's witnesses. Finally, Akayesu argues that in not advising Akayesu of his right to testify, or encouraging testifying, his defense counsel were ineffective. Id.

209. Appellate Chamber Judgment, Akayesu's Ground of Appeal $\mathbb{1} 60$.

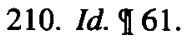

211. Id. I 61. The Appeals Chamber relied on a past decision, Prosecutor v. Kambanda, in holding:

[I]n the light of textual and systematic interpretation of the provisions . . from the Human Rights Committee and the organs of the European Convention for the

Protection of Human Rights and Fundamental Freedoms, that the right to free legal assistance by counsel does not confer the right to choose one's counsel. Id. (citing ICTR 97-23).

212. Id.

213. Id. I 65-66.

214. Id. I 76-77. The Appeals Chamber noted the right to competent counsel is guaranteed under Article 14 of the ICCPR, Article 6 of the European Convention on Human Rights, and Article 8 of the American Convention on Human Rights. Id.

215. Id. II 78.

216. Id. I 77. 
adopting the ICTY case, Prosecutor v. Dusko Tadic. ${ }^{217}$ The standard of determining effectiveness is then a fact based determination where the Appeals Chamber appears unwilling to "second-guess" the decisions of trial defense counsel. ${ }^{218}$ On a final note, it should appear troubling that so little due process analysis was conducted regarding Akayesu's complaints. While his appeal may be novel from the ICTR perspective, such complaints are routinely addressed, as is shown below, in United States courts. The Akayesu decision additionally gains relevance because it created a minimum standard for later trials before international tribunals; military defense counsel practicing before military commissions will have formal professional responsibility rules and Sixth Amendment case-law which will likely result in a far-higher quality of representation.

\section{c. International Tribunal for former Yugoslavia (ICTY)}

\section{Background Facts in Brief:}

The history of the Balkan landmass in Southeast Europe has been characterized by successive invasions. ${ }^{219}$ These invasions, coupled with the region's mountainous geography, created ethnic and religious enclaves. Christians, including both Orthodox and Catholic, as well as Muslims reside in the Balkans. ${ }^{20}$ Within the region formerly called Yugoslavia, ethnicities such as Serb, Croat, Bosnian, Slovene, Montenegrin, Kosovar, and Albanian resided. ${ }^{221}$ Added to this makeup was the fact that from the fourteenth century, until the early twentieth century, Ottoman Turkey ruled much of the landmass as part of its empire. ${ }^{222}$ Additionally, the territory not held by the

217. Id. (citing Prosecutor v. Tadic, Case No. IT-94-1-A, App. Ch., July 15 1999). In that case, the ICTY Appeals Chamber held:

[W] hen evidence was not called because of the advice of defence counsel in charge at the time, it cannot be right for the Appeals Chamber to admit additional evidence in such a case, even if it were to disagree with the advice given by counsel. The unity of identity between client and counsel is indispensable to the workings of the International Criminal Tribunal. If counsel acted despite the wishes of Appellant, in the absence of protest at the time, and barring special circumstances which do not appear, the latter must be taken to have acquiesced.

Id.

218. Id.

219. See Deborah L. Ungar, Comment, The Tadic War Crimes Trial: The First Criminal Conviction Since Nuremburg Exposes the Need for a Permanent War Crimes Tribunal, 20 WHITTIER L. REV. 677-83 (1999).

220. See, e.g., Kellye L. Fabian, Proof \& Consequences: An Analysis of the Tadic \& Akayesu Trials, 49 DEPAUL L. REV. 981,984 (2000).

221. Id. (citing BRANIMIR ANZULOVIC, HeAVENLY SERBIA: FROM MYTH TOGENOCIDE 1-2 (1999)).

222. Fabian, supra note 220 , at 984. 
Ottomans was frequently under the control of neighboring European states. ${ }^{223}$ In 1919, Yugoslavia was formed from these ethnic enclaves into a single country. ${ }^{224}$ Serbs constituted the most numerous, but not the majority, ethnicity. ${ }^{225}$ Prior to 1945 civil strife between ethnic groups based on territorial claims, religious differences, and nation rights claims permeated the area. During the period of Nazi occupation (1940-1945), German troops relied on Croat leaders to suppress the Serb population. ${ }^{226}$ However, after the war, procommunist forces, under Joseph Broz Tito, gained control over Yugoslavia and prevented the country from splitting into separate ethnic-based states. ${ }^{227}$ With Tito's death in 1980, the collapse of the Soviet Union, and a rise in Serb nationalist movements, Yugoslavia began to split apart. On 25 June 1991, Croatia and Slovenia declared independence. ${ }^{228}$ The leader of Yugoslavia, Slobodan Milosevic, a Serb, ordered the army to invade Slovenia. ${ }^{229}$ After European intervention, Milosevic then turned the Serbian army toward Croatia. ${ }^{230}$ In January 1992, the United Nations brokered a cease-fire between Croatia and Serbia. ${ }^{231}$ During this time ethnically diverse Bosnia-Herzegovina (Bosnia), another Yugoslav province, declared its independence. ${ }^{232}$ Within that province Muslims and Croats found themselves fighting Serbs. ${ }^{233}$ From 1992 until 1995, Serbian military and paramilitary groups engaged in a pattern of human rights abuses that came to be known under the umbrella label "ethnic cleansing."234

\section{Statute:}

The ICTY was established in 1993 to prosecute war crimes committed during the conflict which began with the dissolution of that country in $1991 .{ }^{235}$ Specifically, on 23 May 1993, the Security Council adopted Resolution 827

223. Id.

224. Id. at 985 .

225. Id.

226. See, e.g., Michael. P. Sharf, Balkan Justice: The Story Behind THE FiRst INTERNATIONAL WAR CRIMES TRIAL SINCE NUREMBURG 22 (1997) (citing Serbia's Ghosts: Why the Serbs See Themselves as the Victims, Not the Aggressors, NEWSWEEK, Apr. 19, 1993, at 30. According to Sharf, over 500,000 Serbs were killed by the Croat Ustasha (pro-Nazi) movement in concentration camps.) Id. at 23.

227. Fabian, supra note 220 , at 987.

228. Id.

229. Id.

230. Ungar, supra note 219 , at 683 .

231. Id.

232. Id.

233. Id.

234. Fabian, supra note 220, at 987 (citing BOGDAN DENITCH, ETHNIC NATIONALISM: THE TRAGIC DEATH OF YugOSLAVIA 7 (rev. ed. 1994)). Ethnic cleansing is described as "the forcible expulsion of nondominant ethnic groups in a given canton.". Id.

235. U.N. Doc. S/RES/25704, Annex (1993), reprinted in 32 ILM 1192 (1993). 
creating the ICTY. ${ }^{236}$ As in the later case of the ICTR, the ad hoc Yugoslavia Tribunal possessed jurisdiction over specific crimes including genocide, crimes against humanity, and offenses under common article 3 of the Geneva Convention. ${ }^{237}$ Accompanying Resolution 827 was a directive on the appointment of defense counsel. ${ }^{238}$ The ICTY directive also recognized an accused's right to counsel. ${ }^{239}$ This right exists whether or not the accused can afford to remunerate counsel. ${ }^{240}$

There are basic qualifications for the assignment of defense counsel. Unlike in the later ICTR directive discussed above, however, there is no minimum experience requirement for defendants in the ICTY. ${ }^{241}$ Additionally, within the directive, there is no specific guarantee of the right to competent

236. U.N. Doc. S/RES/25704, Annex (1993), reprinted in 32 ILM 1192 (1993).

237. Id.

238. Id.

239. Id. art. 5. This article reads: Without prejudice to the right of an accused to conduct his own defence:

i. a suspect who is to be questioned by the Prosecutor during an investigation;

ii. an accused upon whom personal service of the indictment has been effected; and,

iii. any person detained on the authority of the Tribunal, including any person detained in accordance with Rule 90

bis shall have the right to counsel.

240. Id. art. 6. This article reads: Right to assigned counsel:

A. Suspects or accused who lack the means to remunerate counsel shall be entitled to assignment of counsel paid for by the Tribunal.

B. A suspect or accused lacks the means to remunerate counsel if he does not dispose of means, which would allow him to remunerate counsel at the rates provided for by the Directive. For the purposes of Section III of this Directive, the remuneration of counsel also includes counsel's expenses.

C. For suspects or accused who dispose of means to partially remunerate counsel, the Tribunal shall pay that portion, which the suspect or accused does not have sufficient means to pay for.

Id.

241. Id. art. 14. Article 14 states in part:

(A) Any person may be assigned as counsel if the registrar is satisfied that he is admitted to the list of counsel envisaged in Rule 45(B) of the Rules. A person is eligible for admission to the list if:

i. he is admitted to the practice of law in a State, or is a university professor of law.

ii. he has not been found guilty in relevant disciplinary proceedings against him where he is admitted to the practice of law or a university professor, and has not been found guilty in relevant criminal proceedings against him;

iii. he speaks one of the two working languages of the Tribunal, except if the interests of justice do not require this.

iv. he possesses reasonable experience in criminal and/or international law;

v. he agrees to be assigned as counsel by the Tribunal to represent any indigent suspect or accused;

vi. he is, or is about to become, a member of an association of counsel practicing at the Tribunal. 
counsel. However, discussion of this right appeared during later case proceedings.

\section{Case Example: Prosecutor v. Dusko Tadic}

\section{A. Tadic's Role in the Ethnic Cleansing Program}

Dusko Tadic is an interesting case study for several academic reasons, be these psychological or historic. ${ }^{242}$ In the legal context, his case represents the first real post World War II analysis of due process in an international tribunal. Tadic's actual role occurred in the Prijedor region of Bosnia. Serbian forces were responsible for expelling or killing over 52,000 non-Serbs during the Serb occupation of the region. It was during this time that three prison camps were established: Omarska, Keraterm, and Trnopolje. At each of these camps human rights were routinely ignored as prisoners were beaten, killed, and in the case of females, raped. ${ }^{243}$ During this time Tadic "employed" himself at Omarska where he took part in beating and killing prisoners. ${ }^{244}$ In 1992, he immigrated with his family to Germany where he was later recognized. ${ }^{245}$

Most of Tadic's appeal complaints dealt with the conduct of the trial. Namely, Tadic argued an "inequity of arms" between the resources of the prosecution and defense denied him a fair trial. ${ }^{246}$ In reviewing Tadic's appeal, the Appeals Chamber relied on the plain language of regional agreements as well as the ICCPR. It concluded that the right to a fair trial is "central to the rule of law." ${ }^{47}$ However, the Appeals chamber did not agree Tadic had been denied a fair trial. ${ }^{248}$ This later point is interesting because it ignored that while Tadic's Appeal was being decided, contempt proceeding were initiated against his former lead trial defense counsel.

\section{B. Contempt Allegations Against Tadic's Defense Counsel:}

Milan Vujin represented Tadic throughout the proceedings in differing capacities. During the pretrial stages, he served Tadic as a "non-assigned co-

242. See, e.g., Ungar, Tadic War Crimes Trial, supra note 219, at 688. Tadic is of Bosnian ethnicity. He grew up in the chiefly Muslim town of Kozarac. Prior to the advent of Serb nationalism during the breakup of Yugoslavia, Tadic owned a pub that was financed by Muslim friends. His best friend, who he later killed at Omarska, was Muslim. When the Serbian paramilitary attacked Kozarac, Tadic identified prominent Muslims. Id.

243. Ungar, supra note 219 , at 684.

244. See Tadic, Appeal, 930.

245. Fabian, supra note 219, at 999.

246. See Prosecuter v. Pusico Tadic, Appeal $\mathbb{I} 30$.

247. Id. 943.

248. Id. 
counsel," without formal pay. ${ }^{249}$ Vujin also represented Tadic as formal assigned counsel during the latter's appeal process. ${ }^{250}$ The appeal process included further witness interviews in the RS. These interviews occurred, with Tadic present, in a Prijedor police station on March 14, 1998. ${ }^{251}$ In October 1998, the prosecution filed a motion with the ICTY Appeals Chamber alleging that Vujin and Tadic intimidated witnesses. ${ }^{252}$ However, on November 4, 1998, the Appeals Chamber dismissed the prosecution's complaint for lack of evidence. ${ }^{253}$ After the dismissal, the prosecution received further witness complaints of intimidation. The prosecution renewed its complaint of intimidation to the Appeals Chamber who agreed to revisit its earlier determination. ${ }^{254}$ On November 11, 1999, the Chamber held Vujin in contempt under Rule 77 of the ICTY Rules of Evidence and Procedure. 255

The Appeals Chamber first concluded it possessed an "inherent power" to adjudicate contempt proceedings. ${ }^{256}$ However, it also recognized that standards of contempt are found neither in codified or customary international law. ${ }^{257}$ Instead, the Appeals Chamber relied on the IMT Charter of 1945 which gave that tribunal the power to deal with "any contumacy [by] imposing appropriate punishment, including exclusion of any Defendant or his Counsel

249. Prosecutor v. Tadic, Judgment on Allegations of Contempt Against Prior Counsel, Milan Vujin, 31 Jan. 2000, Pg 1 [hereafter Contempt Proceeding].

250. Id.

251. Id. II 7.

252. Id. $\mathbb{1} 8$.

253. Id.

254. Id. II 11.

255. Id. Rule 77 reads as follows:

(A) Any person who

(i) being a witness before a Chamber, contumaciously refuses or fails to answer a question,

(ii) discloses information relating to those proceedings in knowing violation of an order or a

Chamber; or

(iii) without just excuse fails to comply with an order to attend before or produce documents before a Chamber,

Commits a contempt of the Tribunal.

(B) Any person who threatens, intimidates, causes injury, or offers a bribe to, or other wise interferes with, a witness who is giving, has given, or is about to give evidence in proceeding before a Chamber, or a potential witness, commits a contempt of the Tribunal.

(C) Any person who threatens, intimidates, causes injury, or offers a bribe to, or other wise seeks to coerce any other person with the intention of preventing that other person from complying with an obligation under an order of a Judge or Chamber, commits a contempt of the Tribunal.

(D) Incitement to commit, and attempts to commit, any of the acts punishable under this Rule are punishable as contempts of the Tribunal with the same penalties....

Id. 
from some or all further proceedings, but without determination of the charges."258 The Appeals Chamber also recognized that under common law, courts have the inherent authority to adjudicate and determine contempt. Based on a finding of contempt against Vujin, the Appeals Chamber fined him DfL 15,000 and directed the registrar to consider striking him from the list of acceptable defense counsel. ${ }^{259}$

On appeal, Tadic challenged the competency of Vujin as his defense counsel as part of his overall right to a fair trial. ${ }^{260}$ In doing so, he asked the Appeals Chamber for leave to amend his appeal. ${ }^{261}$ The Appeals Chamber, in turn, denied Tadic leave to do so, ignoring due process considerations, such as the right to conflict-free counsel. ${ }^{262}$ However, on October 5, 2001, Tadic further motioned the Appeals Chamber for reconsideration of its decision regarding the competency of Vujin. ${ }^{263}$ He specifically argued Vujin's behavior leading to contempt, were contrary to his interest in securing a fair trial. ${ }^{264}$ One of Tadic's stronger arguments basically centered Vujin de facto freezing witness testimony to the detriment of his defense. ${ }^{265}$

On July 30, 2002, the Appeals Chamber ruled against Tadic. ${ }^{266}$ The Appeals Chamber analyzed his arguments under the ICTY new evidence rule, instead of the right to conflict free counsel. ${ }^{267}$ The Appeals Chamber noted in the contempt proceeding that Vujin had acted against the interests of his client. ${ }^{268}$ However, it did not apply Vujin's conduct to the whole of the Tadic trial. ${ }^{269}$ Instead, the Appeals Chamber held Tadic was aware of Vujin's activities during the period he was represented by Vujin. ${ }^{270}$ Additionally, Tadic was

258. Id. (citing IMT Charter).

259. Vujin, $\mathbb{1} 174$.

260. Tadic Appeal $q 21$.

261. Id.

262. Id.

263. IT-94-1-R, Decision on Motion for Review 30 July 2002, I 5.

264. DMR, TT 8-9.

265. Id. TI 6-7.

266. DMR, 943.

267. Id. I 19. ICTY Rule 119 governs requests for review and states:

Where a new fact has been discovered which was not known to the moving party at the time of the proceedings before a Trial Chamber or the Appeals Chamber, and could not have been discovered through the exercise of due diligence, the defence or, within one year after the final judgment has been pronounced, the Prosecutor, may make a motion to that Chamber for review of the judgment. If, at the time of the request for review, any of the Judges who constituted the original Chamber are no longer Judges of the Tribunal, the President shall appoint a Judge or Judges in their place.

Id.

268. IT-94-1-R, I 54.

269. Id.

270. Id. 
represented at times by four other lawyers. ${ }^{271}$ In this vein, the Appeals Chamber held, "it may be reasonably inferred that the four lawyers who assisted Tadic during trial could adequately protect his interests and conduct further investigations counter-balancing the initial conduct of Vujin."272 Thus the Appeals Chamber sidestepped a basic due process rights analysis. The Appeals Chamber did not, in detail, investigate how deeply Vujin contaminated Tadic's defense. Nor did the Appeals Chamber address the fundamental right of conflict free counsel. The Chamber barely conducted a "harmless error" analysis prevalent in United States trials. In essence, the Appeals Chamber had the opportunity to further define due process under international law and failed to do so.

\section{III: THE RIGHT TO EFFECTIVE ASSISTANCE OF COUNSEL IN UNITED STATES AND COMMON LAW: REEXAMINATION OF THE RIGHT TO A FAIR TRIAL}

Any analysis of due process applications to military commissions must first begin with a recognition that defense counsel are guided, in part, within the evolving framework of domestic law. While rules for professional responsibility are discussed in another section, the framework of the effective assistance of counsel is rooted in the Sixth Amendment right to counsel as well as a part of the overall concept of a fair trial. To understand the legal expectations on defense counsel before the tribunal, it is essential to review these expectations through the federal and military domestic legal system. In large part, these two systems coexist as a mirror of each other. ${ }^{273}$ This is particularly true where effective assistance of counsel is reviewed. Unlike in the international system, however, the federal and then later, military courts came to guarantee effective assistance of counsel through a lengthy historic process.

\section{a. Brief Note on the History of the Right to Counsel in the United States and Common Law:}

In the 17th Century, criminal trials did not constitute a case in the modern sense. Rather, as one legal historian notes, a criminal trial was akin to "a race between the King and the prisoner with the King having a long start

271. Id. $\mathbb{1}$ 55. The four other lawyers were Mr. Wladmiroff, Mr. Orie, Mr. Kay, and Mr. De Bertodano. Id.

272. Id.

273. Over time, the court-martial has come to substantively mirror the federal criminal court system. See, e.g., United States v. Smith, 27 M.J. 242 (CMA 1988). There are, however, specific rights of military members not found in state and federal courts, such as the legal protection against unlawful command influence. See, e.g., Weiss v. United States, 510 U.S. 163(1994); Curry v. Secretary of the Army, 595 F.2d 873, 879 (1979); United States v. Stoneyman, 57 M.J. 35, 41 (2002), reaffirming unlawful command influence as "the mortal enemy of military justice." 
and the prisoner heavily weighted."274 Prosecutors were not employees of the crown, but instead representatives of a private party, usually the victim. ${ }^{275}$ Both the defendant and the jurors were able to cross-examine prosecution witnesses. ${ }^{276}$ However, a defendant faced impediments to receiving a fair trial. For instance, the defendant was not informed of the specific charges. ${ }^{277}$ Additionally, there existed no right to obtain witnesses or other evidence. ${ }^{278}$ In misdemeanor and trespass cases, an accused was entitled to counsel provided he or she could pay for one. ${ }^{279}$ For the most serious offenses, such as murder and treason, a defendant was prohibited from employing a lawyer to assist in his defense. ${ }^{280}$ This common-law rule remained until the middle of the Eighteenth Century. ${ }^{281}$

During the early part of the Eighteenth Century, the position of prosecutor evolved from private entity to crown employee. ${ }^{282}$ Thus it might be seen that the ability to retain defense counsel for all persons accused, regardless of the severity of crime, became a matter of fairness. Additionally, William Blackstone (1723-1780), one of the most prominent jurists in western legal history, criticized the prohibition against defense counsel for heinous offenses. ${ }^{283}$ The evolution of the prosecutor from private representative to public office and Blackstone's view resulted in the English courts departing from the common-law prohibition against defense counsel. In such a system, the development of custom led to the development of new law. ${ }^{284}$ However,

274. James J. TOMkovicz, THE Right to the AsSistance of COUNSEL: A Reference Guide to the United STATES Constitution 2 (quoting 1 STEPHEN, A History of THE CRIMINAL LAW OF ENGLAND 397).

275. Id. at 3 (quoting John H. Langbein, The Origins of Public Prosecution at Common Law, 17 AM J. LeGAL HIST. 313, 316-17 (1973)).

276. $I d$.

277. Id.

278. Id.

279. Id.

280. Id. Tomkovicz notes that "[s]elf preservation was the core reason that the [crown] denied counsel to those accused of the most serious crimes... Serious crimes and treason were prominent among the perils that jeopardized the very existence of the state." Id. He also notes that legal jurists argued the common law prohibition represented a view that felony trials were "sufficiently simple for an accused - at least an innocent accused - to cope with by himself." Id. (quoting Theodoe F. PlukNetT, A Concise History of the Common LAw (London: Butterworth \& Co., 4th ed. 1948)).

281. TomKovicz, supra note 274 , at 3 . However, note the Treason Act of 1695 stated in part:

nothing is more just and reasonable, than that persons prosecuted for high treason and misprision of treason, whereby their liberties, lives, honour, estates, blood, and posterity of the subjects, may be lost and destroyed, should be justly and equally tried, and ... should not be debarred of all just and equal means for defence of their innocencies in such cases.

Id. at 6 .

282. See, e.g., ToMKOVICZ, supra note 274 , at 5.

283. Id. at 6 .

284. Id. 
no uniform rules for the role of defense counsel or expectations of zealous representation emerged during this period. Yet, it may be the case that the attorney client relationship was already cemented into cornmon law, and criminal trials adopted this practice. ${ }^{285}$ The most significant feature of defense counsel representation occurred in the 1747 Act of Parliament which provided the right to defense counsel representation for high treason cases. ${ }^{286}$

When the thirteen colonies gained independence, there was, on both sides of the Atlantic, movement toward permitting defense counsel in all criminal cases. ${ }^{287}$ Moreover, even prior to independence, there appeared a greater use of defense counsel in criminal trials. ${ }^{288}$ Thus, by the time the Sixth Amendment was drafted into the Constitution, the former colonies fully departed from the older common law based prohibition. Yet, it was not until the twentieth century that the right to counsel was given to mean an absolute right extending to indigents at both state and federal trials.

\section{b. Trials in United States Civilian and Military Courts: A Basic Overview of the Right to Counsel and Effective Assistance of Counsel:}

The right of an accused to a fair trial is rooted in the Sixth Amendment. ${ }^{289}$ Likewise domestic United States Law recognizes a constitutional right to counsel at all federal criminal trials. ${ }^{290}$ Currently, it is debatable whether the Sixth Amendment directly applies to military commissions. However, the Sixth Amendment's shadow will influence the defense counsel's conduct of representation before the commissions.

In a landmark 1963 case, Gideon $v$. Wainwright, ${ }^{291}$ the Court extended the right to defense counsel to all state felony trials. ${ }^{292}$ In 1972, the Court

285. See, e.g., Norman K. Thompson \& Joshua E. Kastenberg, The Attorney-Client Privilege: Practical Military Applications of a Professional Core Value, 49 A.F. L. REV. 1, 3 (2000).

286. TomkovICZ, supra note 274 , at 8 (citing 20 George II, c. 30 (1747)).

287. See id.

288. Id. at 12. Noting that the colonial legislatures of both Rhode Island and South Carolina acknowledged the right of defense counsel as early as 1731 .

289. Johnson v. Zerbst, 304 U.S. 458 (1938). In Johnson, the Supreme Court held:

The Sixth Amendment stands as a constant admonition that if the constitutional safeguards it provides be lost, justice will not "still be done." It embodies a realistic recognition of the obvious truth that the average defendant does not have the professional legal skill to protect himself when brought before a tribunal with power to take his life or liberty, wherein the prosecution is presented by experience and learned counsel.

Id. at $462-63$.

290. Id.

291. 372 U.S. 335 (1963).

292. Id. at 344 . The Court specifically held, "[I]n our adversary system of criminal justice, any person haled into court, who is too poor to hire a lawyer, cannot be assured a fair trial unless counsel is provided for him." Id. at 344 . 
extended the right to counsel in all criminal trials. ${ }^{293}$ The right to counsel is recognized under military law as well. ${ }^{294}$ In part, this right is recognized because military trials have evolved into a "mirror" of federal criminal trials. ${ }^{295}$ In all trials, a knowing and intelligent waiver of this right may permit an accused to proceed under pro se representation. The standard of "knowing and intelligent" is primarily designed to protect an ill-informed or mentally deficient accused-albeit not to the point of inability to stand trial-from waiving what is now accepted as a fundamental right. ${ }^{296}$ However, the right to counsel is generally a courtroom right and does not extend into the pretrial investigation stages. ${ }^{297}$ The chief exception to this general rule involves interrogations and other occasionally, questioning. ${ }^{298}$

The right to counsel does not confer a right to "choice of counsel." The court in Powell v. Alabama ${ }^{299}$ held an accused, has the right to "a fair opportunity to secure counsel of his own choice." 300 However, this right may recede if the scheduling of cases becomes unduly disrupted. ${ }^{301}$ A common exception to the choice of counsel rule occurs as a result of conflict of interest issues. ${ }^{302}$ Additionally, the right to choice of counsel is significantly less when the counsel is court appointed for reasons of the accused's indigence. In Caplin $\&$ Dysdale v. United States, ${ }^{303}$ the Court held, "those who do not have the means to hire their own lawyers have no cognizable complaint so long as they

293. See Argersinger v. Hamlin, 407 U.S. 25, 66 (1972).

294. See, e.g., United States v. Wattenbarger, 21 M.J. 41, 45 (CMA 1985) (citing United States v. Adams, 45 CMR 175 (CMA 1972)); United States v. More, 16 CMR 56, 60 (CMA 1954); Thompson \& Kastenberg, supra note 285, at 1-6.

295. Id.

296. See, e.g., Zerbst, 304 U.S. at 464. See also Rastrom v. Robbins, 319 F. Supp 1090 (D. Me. 1970), aff'd 440 F.2d 1251; United States ex. rel. Pugach v. Mancusi, 310 F. Supp. 691 (S.D.N.Y. 1970), aff'd 441 F.2d 1073 (2d Cir. 1971).

297. See, e.g., Schnecklolth v. Bustamonte, 412 U.S. 218,36 L. Ed. 2 d 854, 93 S. Ct. 2041 (1973). In Schneckloth, the Court held police were not required to apprise a suspect of his Fourth Amendment rights prior to conducting a lawful search. Id. See also Gilbert v. California, 388 U.S. 263, 18 L. Ed. 2d 1178, 87 S. Ct. 1951 (1967). In Gilbert, the Court held an accused does not have the right to have counsel present during the taking of handwriting exemplars. Id. See also Schmerber v. California, 384 U.S. 757, 16 L. Ed. 2 d 908, 86 S. Ct. 1826 (1966). In Schmerber, the Court held that a police extraction of an accused's blood sample does not require the presence of counsel. Id. Likewise, the federal appellate and district courts are replete with cases indicating $s$ suspect does not enjoy the right to counsel during fingerprinting. See, e.g., United States v. Terry, 702 F.2d. 299 (2d Cir. 1983). See also Woods v. United States, 397 F.2d 156 (9th Cir. 1968); Pearson v. United States, 389 F.2d 684 (5th Cir. 1968); and United States v. Whitfield, 378 F. Supp. 184 (E.D. Pa. 1974)

298. See, e.g., Miranda v. Arizona, 384 U.S. 436, 472 (1966); Rhode Island v. Innis, 446 U.S. 291, 64 L. Ed. 2d 297, 100 S. Ct. 1682 (1980).

299. 287 U.S. 45 (1932).

300. Id. at 53 .

301. See, e.g., Downing v. Le Britton, 550 F.2d 689 (1st Cir. 1977).

302. See, e.g., United States v. Moscony, 927 F.2d 742 (3d Cir. 1991).

303. 491 U.S. 617, 105 L. Ed. 2d 528, 109 S. Ct. 2646 (1989). 
are adequately represented by attorneys appointed by the courts." 304 This ruling does not mean an accused is completely barred from requesting termination of one court-appointed counsel for another ${ }^{305}$ However, the accused must point to a specific reason for dissatisfaction such as ineffective representation.

The right to counsel includes the right to effective assistance of counsel. ${ }^{306}$ In the case of international law, determining the ineffectiveness of counsel is problematic because such a determination usually occurs after trial at some level of appeal. However, the court in Strickland v. Washington ${ }^{307}$ articulated the Sixth Amendment standard for effective assistance of counsel. To establish reversible error based on ineffective assistance of counsel, an accused must prove:

First, the defendant must show that counsel's performance was deficient. This requires a showing that counsel made errors so serious that counsel was not functioning as the "counsel" guaranteed by the Sixth Amendment. Second, the defendant must show that the deficient performance prejudiced the defense. This requires showing that counsel's errors were so serious as to deprive the defendant of a fair trial, a trial whose result is reliable. ${ }^{308}$

On the same day Strickland was decided, the Court also held in United States $v$. Cronic ${ }^{309}$ that while factors relevant to determining effectiveness are important, effectiveness can only be determined on a case-by-case basis. ${ }^{310}$ Common arguments for ineffective representation include a lack of preparation time, no opportunity for client-counsel interaction, deficient performance of counsel, and unqualified defense counsel. ${ }^{311}$

304. 491 U.S. at 624.

305. See, e.g., Holloway v. Arkansas, 435 U.S. 475 (1979). See also Gandy v. Alabama, 569 F.2d 1318 (5th Cir. 1978); and United States v. Montoya, 13 M.J. 268 (CMA 1982).

306. See, e.g., McMann v. Richardson, 379 U.S. 694 (1970).

307. 466 U.S. 668 (1984).

308. Id. at 688 .

309. 466 U.S. 648, 80 L. Ed. 2d 657, 104 S. Ct. 2039 (1984). For a good analytic discussion of both Strickland and Cronic, see, e.g., Donald A. Dripps, Ineffective Assistance of Counsel: The Case for an Ex-Ante Parity Standard, 88 J. CRIM. L. \& CRIMINOLOGY 1, 27678.

310. Cronic, 466 U.S. at 668 . The government charged Cronic with a mail fraud. His court appointed attorney was a young real-estate lawyer who had no criminal law experience. Additionally, the attorney had only twenty-five days to prepare for trial. The prosecution, on the other hand, had over four years of investigation against Cronic. On appeal, the Tenth Circuit Court of Appeals reversed Cronic's conviction. However, the Supreme Court unanimously reversed the lower court. Id.

311. See generally JOSEPH G. COOK, CONSTITUTIONAL RIGHTS OF AN ACCUSED THIRD ED. Sec. pp 8-67, 8-114. 


\section{c. Military defense counsel in contemplated military commissions}

Just as the United States Constitution vests the authority to create military commissions in the President, the rules for defense representation are also promulgated by his office. ${ }^{312}$ To date, the executive office has not created special regulations governing zealous representation, but the commission order envisions effective representation. It has, however, formed the office of a Chief Defense Counsel. ${ }^{313}$ While it may be the case specialized ethics rules are drawn for this order, the current system appears, from a due process standpoint, better suited to protect the rights of accused Taliban and al-Qaeida defendants than either the ICTR or ICTY. Indeed, military case law alone has a rich trove of parameters. So to, do the ethic's rules appear to surpass the ICTY.and ICTR.

Military attorneys are fully qualified attorneys who are members of a civilian bar. ${ }^{314}$ They are also officers in the armed forces. ${ }^{315}$ There are specific provisions, upheld in case law, to ensure the quality of defense counsel. ${ }^{316}$ For instance, "attorneys" admitted to a bar other than the fifty states or Puerto Rico are unlikely to be permitted to practice before a military court. ${ }^{317}$ One

312. MacDonald, supra note 68, at 19.

313. See, e.g., Department of Defense, Military Commission Instruction, No 4 (30 April 2003). On 30 April 2003, the Department of Defense created the Office of the Chief Defense Counsel. Id. While this office does not create any specialized ethics rules, it does enforce the requirement of zealous representation. Id. For instance, Section C. Detailed Defense Counsel reads:

C. Detailed Defense Counsel

2) Detailed Defense Counsel shall represent the Accused before military commissions when detailed in accordance with references (a) and (b). In this regard, Detailed Defense Counsel shall: defend the Accused to whom detailed zealously within the bounds of the law and without personal opinion as to guilt; Id. represent the interests of the Accused in any review process....

314. Uniform Code of Military Justice (UCMJ) Article 27(b). This article reads: Trial or defense counsel detailed for a general court-martial-

(1) must be a judge advocate who is a graduate of an accredited law school or is a member of the bar of a Federal court, or of the highest court of a State; . . and

(2) must be certified as competent to perform such duties by the Judge Advocate General of the armed force of which he is a member.

Id.

315. Id.

316. UCMJ art. 38(b) governs the practice of civilian counsel before military courts. Upon request, an accused may seek civilian representation at his own expense. Id.

317. See, e.g., In re Application of Skewes, 52 M.J. 562 (AFCCA). In Skewes, the Air Force Court of Criminal Appeals upheld a trial judge's ruling to prohibit representation by an attorney whose qualifications included attending a non-accredited school and being admitted to the Hoopa Indian Tribal Bar. The Court specifically held:

This Court, like all courts, has a legitimate interest in assuring the competency 
of the salient features as to the extent of military representation rests in Colonel Winthrop's book, Military Rules and Precedents, where he appears to state that persons accused before a military commission will have the same counsel rights as those before a court-martial. ${ }^{318}$ While some scholars will undoubtedly argue that Winthrop is of limited value, it should be noted his work continues to be quoted as guidance in court cases today. ${ }^{319}$ Thus, it may be fairly argued that persons before a military commission are entitled to the same guaranteed legal representation as a service member facing courtmartial.

There is a constitutional duty to provide effective assistance of counsel in both civilian and military case law. ${ }^{320}$ A number of cases detail failures constituting ineffective assistance of counsel. For example, in United States v. Zuis, ${ }^{321}$ the Army Court of Military Appeals found that a failure to communicate with an accused constituted ineffective assistance of counsel. ${ }^{322}$ Likewise, failures to research the $\mathrm{law}^{323}$ and raise timely suppression motions have been held to constitute ineffective assistance. ${ }^{324}$ The failure to call witnesses has, for a long while, been a source of ineffective assistance of counsel. $^{325}$ Moreover, flawed trial tactics on the part of the defense, have resulted in cases being overturned. ${ }^{326}$ Finally, providing inadequate advice to an accused has constituted ineffective assistance of counsel. ${ }^{327}$ The require-

of those who practice before it. We may require "high standards of qualification" before admitting an applicant to the bar, provided the qualification has "a rational connection with the applicant's fitness or capacity to practice law."

Id. (citing Schware v. Board of Bar Examiners of New Mexico, 353 U.S. 232, 239 (1957)).

318. WINTHROP, supra note 27 , at 841.

319. See, e.g., Weiss v. United States, 510 U.S. 163 (1994) (holding that the appointment of military judges does not violate due process). See also Solorio v. United States, 483 U.S. 435 (1987) (upholding court-martial jurisdiction based on service membership); Parker v. Levy, 417 U.S. 733 (1974) (upholding the constitutionality of conduct unbecoming an officer as a criminal offense).

320. See, e.g., Powell v. Alabama, 287 U.S. 45 (1932). See also United States v. Scott, 24 M.J. 186, 187 (CMA 1987). In Scott, the Court of Military Appeals adopted the effectiveness test in Strickland. Id.

321. 49 CMR 150 (ACMR 1974).

322. Id.

323. See, e.g., United States v. Rivas, 3 M.J. 282, 287 (CMA 1997)

324. See, e.g., United States v. Travels, 47 M.J. 596 (A.A. Court. Crim. App. 1997). See also United States v. King, 30 M.J. 59 (1986),

325. See, e.g., United States v. Saintaude, 56 M.J. 888 (Army Court. Crim. App. 2002). See also United States v. Sadler, 16 M.J. 982 (ACMR 1983).

326. Rivas, 3 M.J. at 287.

327. See, e.g., United States v. Hancock, 49 CMR 830 (ACMR 1975); United States v. Kelly, 32 M.J. 813 (NMCMR 1991). The Kelly case presents an interesting issue because the court found defense counsel inadequate for permitting his client to enter into a guilty plea where the only evidence was an uncorroborated confession. Id. But see United States v. Lee, 52 M.J. 51,53 (CAAF 1999) (holding the key to effective advocacy need be determined on a case by case basis). U.S. Armed Forces, 1999. 
ment of zealous and effective representation exists in the appellate process as well. $^{328}$

\section{IV: FORMAL RULES OF PROFESSIONAL RESPONSIBILITY}

As noted in the introduction, a study and analysis of the rules for professional responsibility are important to the concept of a fair trial. Just as United States and common law issues of counsel effectiveness help define representation of accused persons before military commissions, so too do the rules for professional responsibility. These rules establish a corpus of guidance, beyond that found for individual defense counsel before the ICTY and ICTR.

The right to effective assistance of counsel is problematic in that ineffective counsel issues are usually discovered after conviction and the imposition of sentence. Determinations of effectiveness are conducted on a case by case basis. ${ }^{329}$ However, rules of professional responsibility provide guidance for ensuring compliance with fair trial standards. This is because the requirement of zealous representation is largely rooted in the Sixth Amendment right to counsel.

Military defense counsel have a unique role. ${ }^{330}$ Unlike their civilian counterparts, they are subject not only to the ethical rules applicable to all attorneys, but also to military law and regulations. ${ }^{331}$ They are ultimately supervised by the very same agency responsible for the prosecution of military crimes. ${ }^{332}$ In addition, they represent clients around the world and are routinely deployed to remote locations such as Bosnia, Kosovo, and Afghanistan. ${ }^{333}$ Thus, in addition to litigation experience before courts-martial and other forum, some military counsel are familiar with topics of international law and war crimes.

Each service branch promulgates ethics rules. These rules are largely based on the American Bar Association's (ABA) Model Rules. ${ }^{334}$ The Army ethics rules are found in the Department of the Army, regulation 27-26 (Army rules). ${ }^{335}$ The Air Force Rules for professional responsibility are found in a document titled, "The Judge Advocate General, Letter No. 92-26" (TJAG

328. United States v. Grostefon, 12 M.J. 431 (CMA 1982).

329. United States v. Lee, 52 M.J. at 53 (1999).

330. Lt. Col. R. Peter Masterson, The Defense Function: The Role of the U.S. Army Trial Defense Service, ARMY LAw 1(2001).

331. Id.

332. Id.

333. Id.

334. See ABA MOdel Rules of Professional Conduct (1983). In August 1983, the ABA adopted the MODEL RULES to replace the ABA MODEL CODE OF PROFESSIONAL RESPONSIBILITY (1980) as the official code of ethics for the ABA.

335. See DEP'T OF ARMY, REG. 27-26, LEGAL SERVICES: RULES OF PROFESSIONAL CONDUCT FOR LAWYERS (May 1992). 
Policy Letter 26). ${ }^{336}$ Finally, the Department of the Navy, covering both Naval and Marine Corps attorneys, has its ethics rules in a document titled, "Navy Judge Advocate General Instruction 5803.1A, Professional Conduct of Attorneys Practicing Under the Supervision of the Judge Advocate General," (Navy Rules). ${ }^{337}$ On rare occasion a service rule of professional responsibility conflicts with a state bar rule. Where this occurs, the service rule takes precedence. ${ }^{338}$ These rules not only apply to active duty military defense counsel, but also reservists and civilian defense counsel practicing before a military court. $^{339}$

Each service branch requires defense counsel to zealously represent a client before courts-martial or administrative proceedings. ${ }^{340}$ Within the scope of representation, there is a further requirement of diligence. ${ }^{341}$ Diligence includes fully investigating the case. ${ }^{342}$ Investigation envisions client communication, ${ }^{343}$ avoiding conflicts of interest, ${ }^{344}$ and prompt action to preserve rights afforded to the accused. ${ }^{345}$ This later category may mean informing law enforcement representatives that all further communication regarding investigative and other trial matters may be addressed only to the defense counsel. ${ }^{346}$

There are ethical parameters to investigating and preparing for a case. For instance, defense counsel may not knowingly use illegal means to obtain evidence or encourage others to do so. Likewise, defense counsel are not permitted to discourage perspective witnesses from communicating with trial counsel. ${ }^{347}$ Because of the possibility that a witness may alter testimony from what the defense counsel recollects occurred in an interview, the ethics rules encourage the presence of a third party. ${ }^{348}$ This is to prevent a defense counsel from becoming a witness during trial. ${ }^{349}$ Where expert witnesses are employed, the service branch rules contemplate respect for the independence

336. See OFFICE OFTHE JUDGE ADVOCATE GENERAL LETTER NO. 92-26, AIR FORCE RULES OF PROFESSIONAL RESPONSIBILITY (Oct. 1992).

337. See NAvy Judge AdVoCate General instruction 5803.1A, Professional CONDUCT OF ATTORNEYS PRACTICING UNDER THE SUPERVISION OF THE JUDGE ADVOCATE GENERAL (1992).

338. See, e.g., TJAG Policy Letter 26, Rule 8.5. See also AFI 51-201, Administration of Military Justice, P1.3 (3 Oct. 1997) (making the Air Force Rules and Standards applicable to all Air Force attorneys).

339. See TJAG Policy Letter 26, introduction.

340. See TJAG Policy Letter 26, Standard 4-4.1; Navy Rule 1.3; and Army Rule 1.3.

341. See TJAG Policy Letter 26, Standard 4-4.1; Navy Rule 1.3; and Army Rule 1.3.

342. See TJAG Policy Letter 26, Standard 4-4.1; Navy Rule 1.3; and Army Rule 1.3.

343. See TJAG Policy Letter 26, Standard 4-3.1; Navy Rule 1.4; and Army Rule 1.4.

344. See TJAG Policy Letter 26, Standard 4-3.5, United States v. Breese, 11 M.J. 17 (CMA 1981); Navy Rule 1.7; and, Army Rule1.6.

345. See TJAG Policy Letter, Standard 4-3.6; Navy Rule 1.2; and Army Rule 1.2.

346. See TJAG Policy Letter, Standard 4-3.6; Navy Rule 3.4; and Army Rule 1.6.

347. See TJAG Policy Letter 26, Standard 4-4.3; Navy Rule 3.7; and Army Rule 3.4.

348. See TJAG Policy Letter 26, Standard 4-4.4; Navy Rule 3.7; and Army Rule 3.4.

349. See TJAG Policy Letter 26, Standard 4-4.5; Navy Rule 3.4; and Army Rule 4.4. 
of the expert. ${ }^{350}$ The ethics rules mandate compliance with discovery requirements. ${ }^{351}$ Moreover, defense counsel are required to present all matters to opposing counsel and the tribunal with truth and candor. ${ }^{352}$

In terms of representing the client, the various service ethics rules recognize that a defense counsel's foremost loyalty is to his or her client. This includes forthrightly advising the client of all matters of relevant law and possible courses for the trial. ${ }^{353}$ While the accused has the right to decide whether to testify, which pleas to enter, and which forum to proceed, the defense counsel, after consultation with the accused, determines which witnesses to call, how to conduct cross-examination, and what pretrial motions should be argued. ${ }^{354}$ It is considered unprofessional conduct to intentionally overstate or understate risks or case prospects to a client in an effort to exert undue influence on the client's plea decisions. ${ }^{355}$ Moreover, defense counsel must advise the client to avoid making extrajudicial statements or communicate with prospective witnesses. ${ }^{356}$ Additionally, defense counsel should advise the client to avoid contact with prospective court-members. ${ }^{357}$ It is often the case that clients will make inconsistent statements, or their efforts to self-investigate the case will be viewed as motivated by a desire to obstruct justice. For this reason, the defense counsel must diligently listen to the client's input and investigate all leads. ${ }^{358}$

Often defense counsel discuss with prosecutors or law enforcement personnel the status of discovery, witnesses, or scheduling matters. Because the perception of an accused is important, it is essential that defense counsel keep their client apprised of these discussions. ${ }^{359}$

At trial, defense counsel are subject to the same basic rules of ethics that bind prosecutors. For instance, an opening statement should only refer to known evidence. ${ }^{360}$ Counsel is not permitted to make misrepresentations of fact to the tribunal. ${ }^{361}$ Also, counsel is forbidden from knowingly presenting

350. See TJAG Policy Letter 26, Standard 4-4.4; Navy Rule 3.3; and Army Rule 3.3. 351. See TJAG Policy Letter 26, Standard 4-4.5; Navy Rule 3.4; and Army Rule 3.4. 352. See TJAG Policy Letter 26, Standard 4-4.5; Navy Rule 3.3; and Army Rule 3.4. 353. See TJAG Policy Letter 26, Standard 4-5.1(a); Navy Rule 1.4; and Army Rule 1.4. 354. See TJAG Policy Letter 26, Standard 4-5.2; Navy Rule 1.4; and Army Rule 1.4. 355. See TJAG Policy Letter, Standard 4-5.1(b); Navy Rule 1.2; and Army Rule 1.2. 356. See TJAG Policy Letter, Standard 4-5.1(c); Navy Rule 3.6; and Army Rule 3.6. 357. See TJAG Policy Letter, Standard 4-5.1(c); Navy Rule 3.5; and Army Rule 3.5.

358. See, e.g., United States v. Polk, 32 M.J. 150, 152 (CMA 1991). In Polk, the accused alleged his defense counsel failed to interview prospective exculpatory witnesses. The Court of Military Appeals remanded the case for further fact-finding on this issue. But see United States v. Grigoruk, 56 M.J. 304, 307 (CAAF 2002). In Grigoruk, the Court of Appeals for the Armed Forces held it was not deficient performance to avoid having an expert testify. Id.

359. See TJAG Policy Letter, Standard 4-6.2(a); Navy Rule 3.3; and Army Rule 3.3.

360. See TJAG Policy Letter, standard 4-7.4; Navy Rule 3.4; and Army Rule 3.4.

361. See TJAG Policy Letter, standard 4-7.4 (opening statement); also, TJAG Policy Letter, Standard 4-7.8. (closing argument); also Navy Rule 3.4; and, Army Rule 3.4. 
false evidence or making frivolous objections. ${ }^{362}$ Witnesses are to be accorded a measure of respect without seeking to humiliate or intimidate the witness. ${ }^{363}$ Moreover, it is often unprofessional conduct to call a witness when counsel knows the witness will assert a testimonial privilege. ${ }^{364}$

One of the perceived difficulties in client representation occurs when a large quantum of facts clearly indicates an accused's guilt and the accused states his or her intention to testify. ${ }^{365}$ This situation does not only happen where an accused notifies defense counsel of his or her intent to lie on the stand. ${ }^{366}$ There are times where a defense counsel is aware of potential client perjury without the client's outright disclosure. ${ }^{367}$ In such situations, the defense counsel is required to dissuade the client from testifying. ${ }^{368}$ Where dissuasion fails, the counsel should not take part in questioning the client on direct examination. ${ }^{369}$ However, a mere suspicion of potential perjury does not preclude participation in direct examination. ${ }^{370}$ Moreover, a defense counsel may seek to withdraw from the representation. ${ }^{371}$ Where withdrawal is not feasible, defense counsel are advised to place in the record of trial evidence of their effort to dissuade their client from testifying. ${ }^{372}$ It should be noted that there are no set means by which to place a record of dissuasion in the record of trial. The best practice is to place as an in camera appellate exhibit, evidence of attempts to dissuade the client from testifying. This is because where a defense counsel learns of the client committing perjury, there is a duty to ex parte disclose to the military judge. ${ }^{373}$

In cases where the accused and the defense counsel cannot cooperate in the construction and presentation of the accused's defense, there are remedies for withdrawal. For instance, in United States $v$. Brownfield, ${ }^{374}$ the Court of Appeals for the Armed Forces recognized, "many times, defense counsel are called upon to represent clients with whom they have a personality conflict.

362. See, e.g., United States v. Pattin, 50 M.J. 637 (ACCA 1999).

363. See TJAG Policy Letter, Standard 4-6.6; and Army Rule 3.4.

364. See TJAG Policy Standard 4-7.6(c); and Army Rule 3.4.

365. See, e.g., Lt Col. R. Peter Masterson, supra note 330, at 1, 6; Lt. Col. Thomas G. Bowe, Limiting the Defense Counsel's Obligation to Disclose Client Perjury After Revealed Adjournment, When Should the Conclusion of Proceedings Occur, 1993 ARMY LAW 27, 29.

366. See, e.g., USALSA Reports: The Advocate for Military Defense Counsel: DAD Notes, 1987 ARMY LAW 34, 35. See also United States v. Roberts, 20 M.J. 689, 691 (ACMR 1989) [hereinafter USALSA Reports]. For additional reading generally, see, e.g., Terrence F. McCarthy \& Kathy Morris Mehjia, The Perjurious Client Question, Putting Criminal Defense Lawyers Between a Rock and a Hard Place, 75 J. L. \& CRIMINOLOGY 1197 (1984).

367. See, e.g., USALSA Reports, supra note366, at 35.

368. See TJAG Policy Standard 4-7.7(a); and Army Rule 3.3.

369. See USALSA Reports, supra note 366, at 35.

370. See, e.g., Nix v. Whiteside, 475 U.S. $157,191,106$ S. Ct. 988,1006 (1986) (the most honest witness may recall (or sincerely believe he recalls) details that he previously overlooked).

371. See TJAG Policy Letter, Standard 4-7.7(b); Navy Rule 3.3; and Army Rule 3.3.

372. See TJAG Policy Letter, Standard 4-7.7(c); Navy Rule 3.3; and Army Rule 3.3.

373. See TJAG Policy Letter, Standard 4-7-7(d); Navy Rule 3.3; and Army Rule 3.3.

374. 52 M.J. 40 (CAAF 1999). 
In these cases, there are two choices: (1) try to resolve the conflict and press forward with full and zealous representation, or (2) seek relief from the obligation to represent the client." 375

Defense counsel have an ongoing duty to represent their client's interests after conviction. This includes all matters in sentencing, as well as in advising the client as to appeal rights. ${ }^{376}$ Counsel representing an accused on appeal have an obligation to investigate and present all meritorious arguments. ${ }^{377}$ This includes researching and arguing ineffective counsel issues related to the defense counsel's performance at trial. ${ }^{378}$

The professional responsibility rules governing defense counsel conduct are comprehensive. These rules provide two guarantees. The first guarantee is to the client, in that persons charged with criminal offenses will receive a defense counsel's zealous and diligent best efforts. The second guarantee is to the integrity and fairness of the proceedings. The rules ensure that accused persons will be represented diligently and ethically within the parameters of professional conduct.

\section{CONCLUSION}

While no military commission has yet commenced, it is likely one will begin in the near future. It is proper to understand the uniqueness of defense representation before a commission. Part of this understanding can be accomplished by a review of developing customary international law and treaty agreements. Likewise, a comparative study and analysis of the closest international law counterparts, the ad hoc tribunals, are important to define fair trial guarantees. These courts of universal jurisdiction present a basis by which to judge fair trial standards of military commissions. Should Akayesu or Tadic have been reviewed before a service appellate court, it is likely both cases would have been reversed on the basis of ineffective assistance of counsel. In the case of Akayesu, it is apparent counsel were occasionally absent from the proceedings and were likely not permitted adequate time to prepare for so large a case. Additionally, Akayesu's counsel employed the questionable tactic of calling an adverse witness as an expert. Tadic is actually an easier case to argue for reversal. Clearly his counsel failed to act in his best interests. Additionally, at some point, his counsel, Vujin, became a conflicted counsel in the most literal sense. It is a basic premise in both federal and military law that an accused is entitled to conflict-free counsel. ${ }^{379}$

375. Id. at 44.

376. See TJAG Policy Letter, Standard 4-8.1 (sentencing); TJAG Policy Letter, Standard 4-8.2 (advice on appeal).

377. See TJAG Policy Letter, Standard 4-8.4; Navy Rule 1.2; and Army Rule 1.2.

378. See TJAG Policy Letter, Standard 4-8.6; Navy Rule 1.2; and Army Rule 1.2.

379. See, e.g., Cuyler v. Sullivan, 446 U.S. 340, 345 (1980). See also United States v. Murphy, 50 M.J. 4, 10 (C.A.A.F. 1998). 
While it is true the jurisdictional basis of the ICTR and ICTY are different from military commission, these forum are the closest existing counterpart to the commission process for comparison.

In the absence of special rules for defense counsel before tribunals, the prudent course is to incorporate tenets of effective representation from United States and military law. These tenets are rooted in Sixth Amendment case law, and the rules for professional responsibility each service branch promulgated, based on the ABA model rules. Indeed, no new rules are required. Within federal and military case law, and the rules for professional responsibility, there is a far more developed and tested set of parameters than found in the international tribunals. While this article touched on only a few cases, a myriad of guidance in case law exists not only at the federal, but also the state courts. Therefore, the suggested framework for representation is to, following the guidance of Colonel Winthrop, adopt no new special measures. Military representation and its attendant standards of effective assistance of counsel surpass any current international tribunal counterpart for courtsmartial. Indeed, the former category, in its infancy, appears to constitute a lessoning of standards for zealous representation. However, the ICTR and ICTY should, at a minimum, set a standard by which to judge military defense counsel. The mechanisms for assuring military defense counsel provide not only competent, but also diligent and zealous representation for accused persons before military commissions which comports with international fair trial standards. There should be no reason to alter these rules. It only remains to be seen whether military defense counsel, and indeed all parties before the commissions, individually uphold and enforce these standards. 
